Original paper

\title{
(Fe,Mn)-(Ti,Sn)-(Nb,Ta) oxide assemblage in a little fractionated portion of a mixed (NYF + LCT) pegmatite from Piława Górna, the Sowie Mts. block, SW Poland
}

\author{
Adam PIECZKA ${ }^{1 *}$, Adam SZUSZKIEWICZ², Eligiusz SZEŁĘG ${ }^{3}$, Krzysztof NEJBERT ${ }^{4}$, \\ Marek ŁODZIŃSKI ${ }^{5}$, Sławomir ILNICKI ${ }^{4}$, Krzysztof TURNIAK ${ }^{2}$, Magdalena BANACH ${ }^{6}$, \\ Władysław HOŁUB ${ }^{6}$, Piotr MICHAŁOWSKI ${ }^{6}$, Roman RÓŻNIAK ${ }^{6}$
}

\footnotetext{
${ }^{1}$ AGH University of Science and Technology, Department of Mineralogy, Petrography and Geochemistry 30-059 Kraków, Mickiewicza 30, Poland; pieczka@agh.edu.pl

${ }^{2}$ University of Wroctaw, Institute of Geological Sciences, 50-205 Wroctaw, Cybulskiego 30, Poland

${ }^{3}$ University of Silesia, Faculty of Earth Sciences, Department of Geochemistry, Mineralogy and Petrography, 41-200 Sosnowiec, Będzińska 60, Poland

${ }^{4}$ University of Warsaw, Faculty of Geology, Institute of Geochemistry, Mineralogy and Petrology, 02-089 Warszawa, Żwirki and Wigury 93, Poland

${ }^{5}$ AGH University of Science and Technology, Department of General Geology and Geotourism, 30-059 Kraków, Mickiewicza 30, Poland

${ }^{6}$ DSS Company, Piława Górna Quarry, 58-240 Piława Górna, Sienkiewicza 96, Poland

* Corresponding author
}

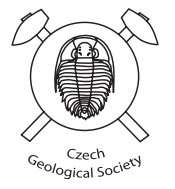

Textural relationships and compositional variations of (Fe,Mn)-(Ti,Sn)-(Nb,Ta) oxides and associated minerals from low- to moderately fractionated, mixed (NYF + LCT) anatectic pegmatites, which belong to the Julianna pegmatitic system, exposed at Piława Górna, Lower Silesia, Poland, were studied to elucidate the geochemical evolution of the pegmatite-forming melt. The primary Nb-Ta oxides crystallized in the following sequence: (1) columbite-(Fe) evolving to columbite-(Mn), associated with $\mathrm{Nb}$ - and Ta-bearing ilmenite-pyrophanite + almandine-spessartine garnet + Ti-poor schorl, (2) columbite-(Fe), (3) tantalite-(Fe), (4) Ti- and Sn-bearing ixiolite \pm ferrowodginite \pm Nb- and Ta-bearing cassiterite \pm columbite-(Fe), all crystallizing along with Ti-enriched schorl evolving to dravite. The most characteristic features of the mineral assemblages are the reversed $\mathrm{Mn}-\mathrm{Fe}$ fractionation trends and increasing Ca concentrations at the final stage of crystallization. These compositional variations are explained by a possible pre-emplacement contamination of the pegmatite-forming melt and re-equilibration of biotite and plagioclase from the early-crystallized outer zones of the pegmatites with rapidly cooling pegmatitic melt. Local changes in melt composition were of minor importance. Late alterations, such as chloritization and muscovitization of biotite or albitization of Ca-rich plagioclase were significant only at the hydrothermal stage.

Keywords: Nb-Ta oxides, mixed NYF + LCT anatectic pegmatites, compositional evolution, reversed Mn-Fe fractionation, Piława Górna, Poland

Received: 20 February 2013; accepted: 29 May 2013; handling editor: R. Škoda

\section{Introduction}

Pegmatites of the Góry Sowie Mountains block (GSB) in Lower Silesia, Poland, have been known for over 200 years. In the 1700s and 1800 s, numerous pegmatitic bodies were mined as a source of raw quartz and feldspar. Historical literature noted the presence of several mineral phases, such as perfectly developed, large crystals of black tourmaline, light-greenish beryl, microcline, rare phosphate minerals as triplite, huréaulite and vivianite, and columbite (Fiedler 1863; Römer 1864; Roth 1867; Traube 1888; Dathe and Finckh 1924; Hintze 1933). The pegmatite at Michałkowa (= Michelsdorf) is the type locality for sarcopside (Websky 1868). The end of mining activity in the area has limited modern mineralogical studies to a few small in situ occurrences, old mining dumps and museum specimens. Nonetheless, a number of minerals have been described, including Li-bearing phosphates, elbaite, and columbite-(Fe) and $\mathrm{Pb}$-bearing microlite occurring as inclusions in beryl (Pieczka et al. 2003, 2004; Łodziński and Pieczka 2008). Novák (2005), in his paper summarizing the current state of knowledge of the Bohemian Massif pegmatites, classified the GSB pegmatites as the beryl subtype of the LCT (lithium-cesium-tantalum) petrogenetic family of Černý and Ercit (2005).

In the 2007, the Dolnośląskie Surowce Skalne S.A Company, one of the largest Polish suppliers of crushed rock aggregates, opened a new quarry near the town of Piława Górna and uncovered the largest pegmatitic 
system known in the GSB. The system, named Julianna, displays a hybrid geochemical signature (Pieczka et al. 2012; Szuszkiewicz et al. in print). Commonly low- to moderately evolved pegmatites contain minerals typical of the NYF (niobium-yttrium-fluorine) petrogenetic family. However, the pegmatites only exceptionally attain a very high degree of geochemical evolution, and also contain typical LCT-signature minerals. Recently, Novák et al. (2012) described pegmatites from Bližná and Kracovice, Czech Republic, as representatives of such a mixed NYF + LCT signature in the Moldanubian Zone.

This paper describes in detail the textural relationships and compositional evolution of the primary (Fe,Mn)$(\mathrm{Ti}, \mathrm{Sn})-(\mathrm{Nb}, \mathrm{Ta})$ assemblage and associated minerals in the low- to moderately evolved pegmatites that largely dominate the Julianna system at Piława Górna (Szełęg et al. 2010; Szuszkiewicz et al. in print). The results are discussed as potential indicators of processes controlling the geochemical evolution of the pegmatite-forming melt. The corresponding mineral assemblage from exceptionally rare, highly-evolved, $\mathrm{Li}-\mathrm{Cs}-\mathrm{Ta}-\mathrm{Be}-\mathrm{B}$ mineralized portions of some of the largest pegmatitic veins will be the subject of a separate study.

\section{Geological setting}

The GSB occupies the central portion of the Sudetes, SW Poland, in the northeastern part of the Bohemian Massif (Fig. 1). The unit is built predominantly by oligoclase-biotite paragneisses, migmatites and orthogneisses, with minor intercalations of anatectic granites and pegmatites, metabasites, granulites, eclogites, marbles and calc-silicate rocks (Polański 1955; Grocholski 1967; Morawski 1973; Kryza 1981; Żelaźniewicz 1987; Gunia 1997; Ilnicki et al. 2010). A greywacke pelitic-psammitic sequence of late Proterozoic to early Cambrian age (Gunia 1985) and I-type, calc-alkaline igneous rocks dated at 518-480 Ma (Kröner and Hegner 1998; Kryza and Fanning 2007) are considered protoliths to the gneisses.

The GSB gneissic complex underwent a polymetamorphic evolution. An older HP-HT metamorphism at $\sim 400$ Ma (Brueckner et al. 1996; O’Brien et al. 1997; Kryza and Fanning 2007) was followed by high amphibolitefacies overpint (Kryza 1981; Żelaźniewicz 1987, 1990, 1997). Five tectonothermal events $\left(D_{1}-D_{5}\right)$ have been recognized in the gneissic-amphibolite suite and the peak metamorphic conditions were ascribed to stages $\mathrm{D}_{2}-\mathrm{D}_{3}$ (Żelaźniewicz 1990). The subsequent decompression caused local partial melting at $\sim 380-370 \mathrm{Ma}$, leading to the formation of anatectic pegmatites, granites, aplites and quartz veins (van Breemen et al. 1988; Bröcker et al. 1998; Timmermann et al. 2000; Aftalion and Bowes 2002; Gordon et al. 2005).

The town of Piława Górna is located $\sim 50 \mathrm{~km}$ southwest of Wroclaw in the eastern part of the GSB. This fragment of the GSB belongs to the Fore-Sudetic Block, the strongly peneplained NE margin of the Sudetes (Fig. 1). A quarry about $100 \mathrm{~m}$ deep, owned by the Dolnośląskie Surowce Skalne S.A Company, is situated $1.5 \mathrm{~km}$ to the north-west of the town $\left(50^{\circ} 42^{\prime} 11.77^{\prime \prime} \mathrm{N}\right.$; $\left.16^{\circ} 44^{\prime} 12.36^{\prime \prime} \mathrm{E}\right)$ and exploits a large migmatite-amphibolite deposit ( 380 million metric tons) for crushed rock aggregates. Migmatitic gneisses composed of quartz, K-feldspars, biotite, subordinate muscovite, garnet, and accessory zircon, apatite and sillimanite, are commonly cut discordantly by leucosome segregations, which in places may be treated as syn-migmatitic pegmatitic granite. Weakly foliated amphibolites, identified as retrogressed eclogite, are built by hornblende and plagioclase with minor garnet, locally abundant biotite, subordinate ilmenite, rutile, clinozoisite, quartz, and accessory relics of clinopyroxene and spinel (Ilnicki et al. 2010). The rocks are cut discordantly by a number of anatectic pegmatite dikes, which intruded tectonized amphibolite. The largest pegmatitic bodies, up to $6 \mathrm{~m}$ thick, were exposed along $30-40 \mathrm{~m}$ in the vertical, and $80-100 \mathrm{~m}$ in the longitudinal sections (fig. 4 in Szuszkiewicz et al. in print). They typically display a low to moderate degree of geochemical fractionation with enhanced Nb-REE-Be-B contents and consist mainly of microcline, plagioclase (oligoclase-andesine and albite), quartz, biotite and muscovite accompanied by common schorl, garnet and beryl. An idealized zone sequence begins with a discontinuous, fine- to medium-grained granitic border zone up to a few centimeters thick that is succeeded by a coarser grained wall zone with distinct unidirectional growth textures, a graphic intermediate zone composed of feldspar-quartz intergrowths and characteristic giant biotite laths (up to $60 \mathrm{~cm}$ long), and a blocky feldspar intermediate zone formed mainly of microcline with subordinate oligoclase-albite. The total thickness of the border and wall zones reaches $\sim 0.3 \mathrm{~m}$, whilst both intermediate zones attain a thickness of c. $2 \mathrm{~m}$. Several decimeter- to metersized quartz cores occur as pockets or lenses roughly along the axial portions of larger dykes. Various $\mathrm{Nb}-\mathrm{Ta}$ minerals, including columbite-group minerals, ixiolite, ferrowodginite, samarskite-, euxenite- and fergusonitegroup minerals, pyrochlore-supergroup minerals, and also $\mathrm{Nb}$ - and Ta-enriched varieties of cassiterite, ilmenite and titanite, constitute important accessory minerals and many of them suggest a NYF signature for the parental melt. However, in exceptionally rare cases, when fractionation attained a very high degree, the LCT-signature mineral assemblage including elbaite-liddicoatite, pollucite, spodumene, Cs-beryl and Li-micas is encountered 


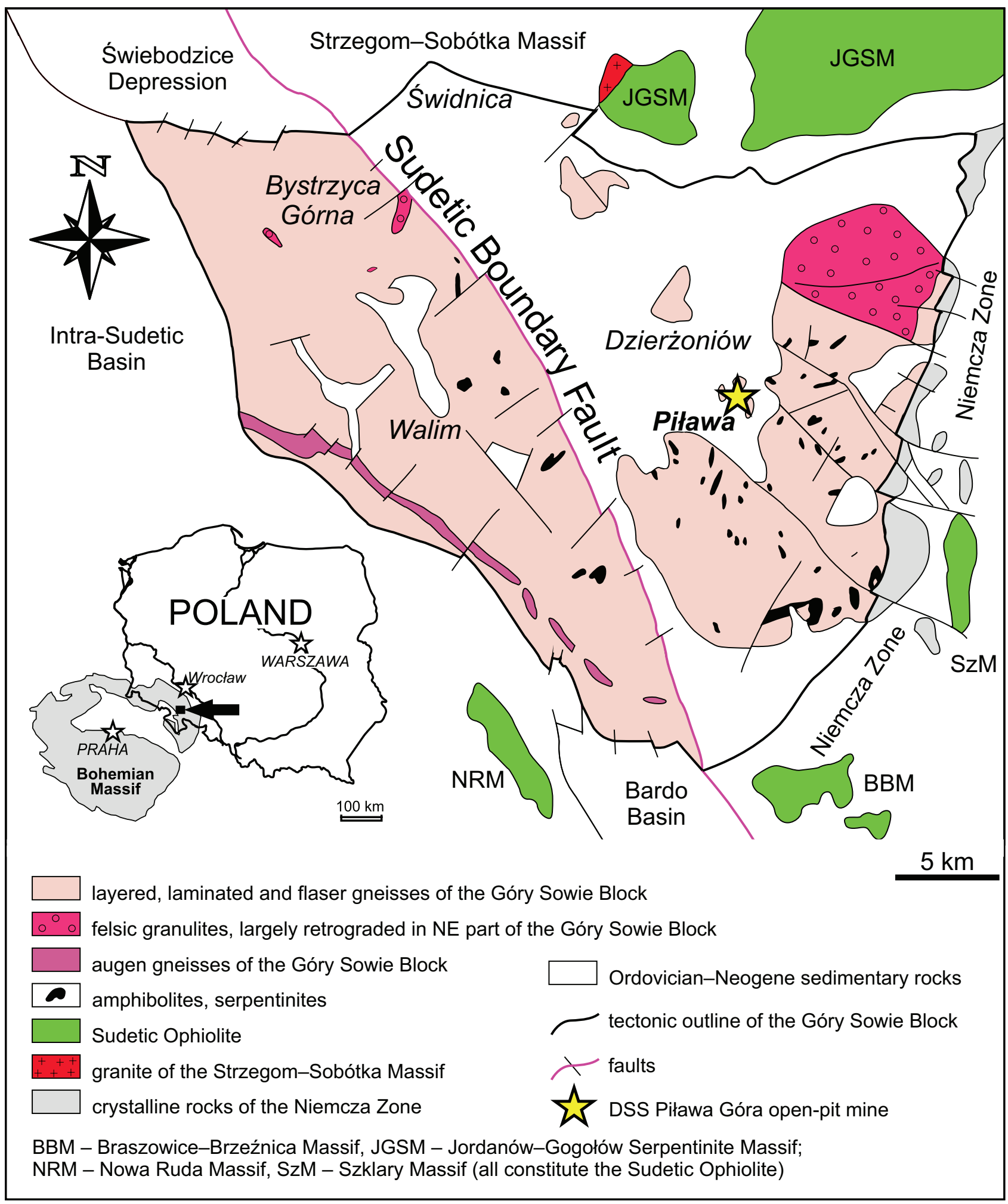

Fig. 1 Geological map of the Góry Sowie Block (after Szuszkiewicz et al. in print).

(Łodziński et al. 2010; Nejbert et al. 2010; Pieczka et al. 2010, 2012; Szełęg et al. 2010). Thus the complex Julianna system of cogenetic pegmatites is tentatively assigned to the mixed NYF + LCT family (Pieczka et al. 2012; Szuszkiewicz et al. in print) of Černý and Ercit (2005). 


\section{Methods}

\subsection{Sampling}

In the Piława Górna quarry, amphibolite and migmatite are quarried together with associated pegmatites by blasting to an amount of about 5 million metric tons per year. Such a large-scale exploitation results in very short average duration of an exposed pegmatitic body, usually a few days. Therefore, direct in situ observations of pegmatites were strongly limited and hand samples were mostly collected from loose blocks detached from the quarry wall after blasting. Although it was always possible to reconstruct the position of a sample within the overall zoning scheme of the pegmatite, identifying a very precise location for each of the analyzed crystals, for instance with reference to the distance from the pegmatite's margins, was not feasible.

\subsection{Analytical procedures}

Samples were prepared in the form of 1-inch discs containing the chosen crystals or crystal aggregates together with adjacent minerals, polished and carbon-coated. Electron microprobe analyses (EMPA) were performed at the Inter-Institute Analytical Complex for Minerals and Synthetic Substances of University of Warsaw with a CAMECA SX 100 electron microprobe in wavelengthdispersive (WDS) mode. Operating conditions were: accelerating voltage of $20 \mathrm{kV}$, beam current of $20 \mathrm{nA}$, beam diameter of $2 \mu \mathrm{m}$, peak count time of $20 \mathrm{~s}$ and background time of $10 \mathrm{~s}$. The following standards, analytical lines and crystals were used: apatite $-\mathrm{F}\left(\mathrm{K}_{\alpha}, \mathrm{TAP}\right)$, albite - $\mathrm{Na}\left(\mathrm{K}_{\alpha}\right.$, TAP), diopside $-\mathrm{Mg}\left(\mathrm{K}_{\alpha}\right.$, TAP) and $\mathrm{Si}$ $\left(\mathrm{K}_{\alpha}\right.$, TAP $)$, orthoclase $-\mathrm{Al}\left(\mathrm{K}_{\alpha}\right.$, TAP) and $\mathrm{K}\left(\mathrm{K}_{\alpha}, \mathrm{LIF}\right)$, wollastonite - $\mathrm{Ca}\left(\mathrm{K}_{\alpha}, \mathrm{PET}\right)$, Sc pure - Sc $\left(\mathrm{K}_{\alpha}, \mathrm{PET}\right)$, rutile - $\mathrm{Ti}\left(\mathrm{K}_{\alpha}, \mathrm{PET}\right), \mathrm{V}_{2} \mathrm{O}_{5}-\mathrm{V}\left(\mathrm{K}_{\alpha}, \mathrm{LIF}\right)$, rhodonite $\operatorname{Mn}\left(K_{\alpha}, L I F\right)$, hematite - Fe ( $K_{\alpha}$, LIF), sphalerite - Zn $\left(\mathrm{K}_{\alpha}, \mathrm{LIF}\right), \mathrm{YAG}-\mathrm{Y}\left(\mathrm{L}_{\alpha}, \mathrm{PET}\right)$, zircon $-\mathrm{Zr}\left(\mathrm{L}_{\alpha}, \mathrm{PET}\right), \mathrm{Nb}$ pure - Nb $\left(\mathrm{L}_{\alpha}, \mathrm{PET}\right)$, cassiterite - $\mathrm{Sn}\left(\mathrm{L}_{\alpha}, \mathrm{PET}\right)$, barite $\mathrm{Ba}\left(\mathrm{L}_{\alpha}, \mathrm{PET}\right), \mathrm{LaP}_{5} \mathrm{O}_{14}-\mathrm{La}\left(\mathrm{L}_{\alpha}, \mathrm{PET}\right), \mathrm{CeP}_{5} \mathrm{O}_{14}-\mathrm{Ce}\left(\mathrm{L}_{\alpha}\right.$, PET), Ta pure - Ta $\left(M_{\alpha}\right.$, TAP), W pure - W $\left(M_{\beta}\right.$, TAP), galena - $\mathrm{Pb}\left(\mathrm{M}_{\alpha}, \mathrm{PET}\right), \mathrm{Bi}_{2} \mathrm{Te}_{3}-\mathrm{Bi}\left(\mathrm{M}_{\alpha}, \mathrm{PET}\right), \mathrm{U}_{3} \mathrm{O}_{8}-\mathrm{U}$ $\left(\mathrm{M}_{\alpha}, \mathrm{TAP}\right), \mathrm{ThO}_{2}-\mathrm{Th}\left(\mathrm{M}_{\alpha}, \mathrm{PET}\right)$. The raw data were reduced with the PAP routine (Pouchou and Pichoir 1985). For comparison of atomic abundances in the studied oxides, the formulae of columbite-group minerals (CGM), ixiolite, ferrowodginite and cassiterite have been normalized to 24 oxygen atoms per formula unit $(a p f u)$, assuming valence charge-balance and a value of the $\mathrm{Fe}^{3+} / \mathrm{Fe}_{\text {total }}$ ratio such as to reduce any surplus in the cation totals over $12 a p f u$, i.e., above the number of the structurally available lattice positions. Thus, the formula of ferrowodginite was taken as $A_{3} B_{3} C_{6} O_{24}$, instead of
$A_{4} B_{4} C_{8} O_{32}$, ixiolite as $(A, B, C){ }_{12} O_{24}$, and CGM as $A_{4} D_{8} O_{24}$, where $A$ denotes $\mathrm{Fe}^{2+}, \mathrm{Mn}, \mathrm{Ca}, \mathrm{Mg}$, and additionally $\mathrm{Li}^{+}$ with vacancies in the wodginite-group minerals (WGM), $B-\mathrm{Sn}, \mathrm{Ti}, \mathrm{Zr}, \mathrm{Hf}, \mathrm{Fe}^{3+}$, Sc and additionally Ta excess in WGM, $C-\mathrm{Nb}$, Ta and $\mathrm{W}$, whilst $D$ includes simultaneously both the $B$ and $C$ components. For distinguishing between minerals of the columbite group, ixiolite and ferrowodginite, only the stoichiometric criteria suggested by Wise et al. (1998) were employed. Accordingly, the term ixiolite was used only for samples with more than 10 mol. $\% \mathrm{SnO}_{2}+\mathrm{TiO}_{2}+\mathrm{ZrO}_{2}+\mathrm{HfO}_{2}+\mathrm{Sc}_{2} \mathrm{O}_{3}+$ $\mathrm{Fe}_{2} \mathrm{O}_{3}$, i.e. $>1.2\left(\mathrm{R}^{3+}+\mathrm{R}^{4+}\right) p f u$, and which do not match the criteria for completely ordered WGM, i.e. Ta $\geq 2$ $\mathrm{Nb}$ at the $C$ site, the sum of $B$-site cations $\mathrm{Sn}+\mathrm{Ti}+\mathrm{Zr}$ $+\mathrm{Hf}+\mathrm{Sc}+\mathrm{Fe}^{3+} \leq 0.5 \mathrm{Ta}+\mathrm{Nb}+\mathrm{W}$, and $\mathrm{Ti}+\mathrm{Sn}+\mathrm{Zr}+$ $\mathrm{Hf}+\mathrm{Sc}+\mathrm{Fe}^{3+}+\mathrm{Ta}_{\text {excess }}$ in $C=3 a p f u$ according to Ercit et al. (1992).

The compositions of pyrochlore-supergroup minerals were normalized to $2 B=(\mathrm{Nb}+\mathrm{Ta}+\mathrm{Ti}+\mathrm{W}+\mathrm{Sn}+\mathrm{Zr}+$ $\left.\mathrm{Al}+\mathrm{Fe}^{3+}\right) a p f u$, with traces of $\mathrm{Si}$ treated as an impurity located outside the pyrochlore structure. All Fe was treated as $\mathrm{Fe}^{3+}$. The $\mathrm{H}_{2} \mathrm{O}$ was calculated by stoichiometry in two alternative ways: (1) for the case of $\mathrm{OH}$ existing in the $X$ site, i.e. when the $\mathrm{O}$ equivalent $\left(\mathrm{O}_{e q}\right)$ equals to half of the total cation charge $<6$, and (2) when $\mathrm{OH}$ exists in the $Y$ site, i.e. for $6.5 \geq \mathrm{O}_{\text {eq. }}>6$, with an assumption that $\mathrm{O}^{2-}$ can appear in the $Y$ site only when $7 \geq \mathrm{O}_{\text {eq. }}>6.5$.

The composition of ilmenite has been normalized to $3 \mathrm{O} p f u$, and the compositions of the coexisting tourmaline supergroup and garnet group minerals to $31(\mathrm{O}, \mathrm{OH}, \mathrm{F})$ and $15(Y+Z+T)$ cations, and $12 \mathrm{O}$, respectively. Biotite compositions were normalized to $22 \mathrm{O}$ pfu. All $\mathrm{Fe}$ was treated as $\mathrm{Fe}^{2+}$ and $\mathrm{OH}^{-}$was calculated by stoichiometry.

The entire set of the EMP data includes $c .600$ spot analyses of CGM and ixiolite, 25-30 analyses of ferrowodginite, cassiterite, ilmenite and minerals of the pyrochlore supergroup each, and 60 analyses for each of tourmaline and garnet, and c. 80 analyses of biotite.

\section{Mineralogy of the $\mathrm{Nb}-\mathrm{Ta}$ assemblage}

In the little fractionated portion of the Julianna pegmatitic system, (Fe,Mn)-(Ti,Sn)-(Nb,Ta) oxides are represented by columbite-group minerals, titanian and stannian ixiolite, ferrowodginite, members of the pyrochlore supergroup, Nb-Ta-bearing varieties of the ilmenite-group minerals and cassiterite.

\subsection{Columbite-group minerals}

Minerals of the columbite group are the most widespread $\mathrm{Nb}-\mathrm{Ta}$ phases, occurring from the inner graphic zone 
(Fe,Mn)-(Ti,Sn)-(Nb, Ta) oxide assemblage in the mixed pegmatite from the Sowie Mts block, Poland

Tab. 1a Representative compositions of a columbite crystal of fractionation style IIa

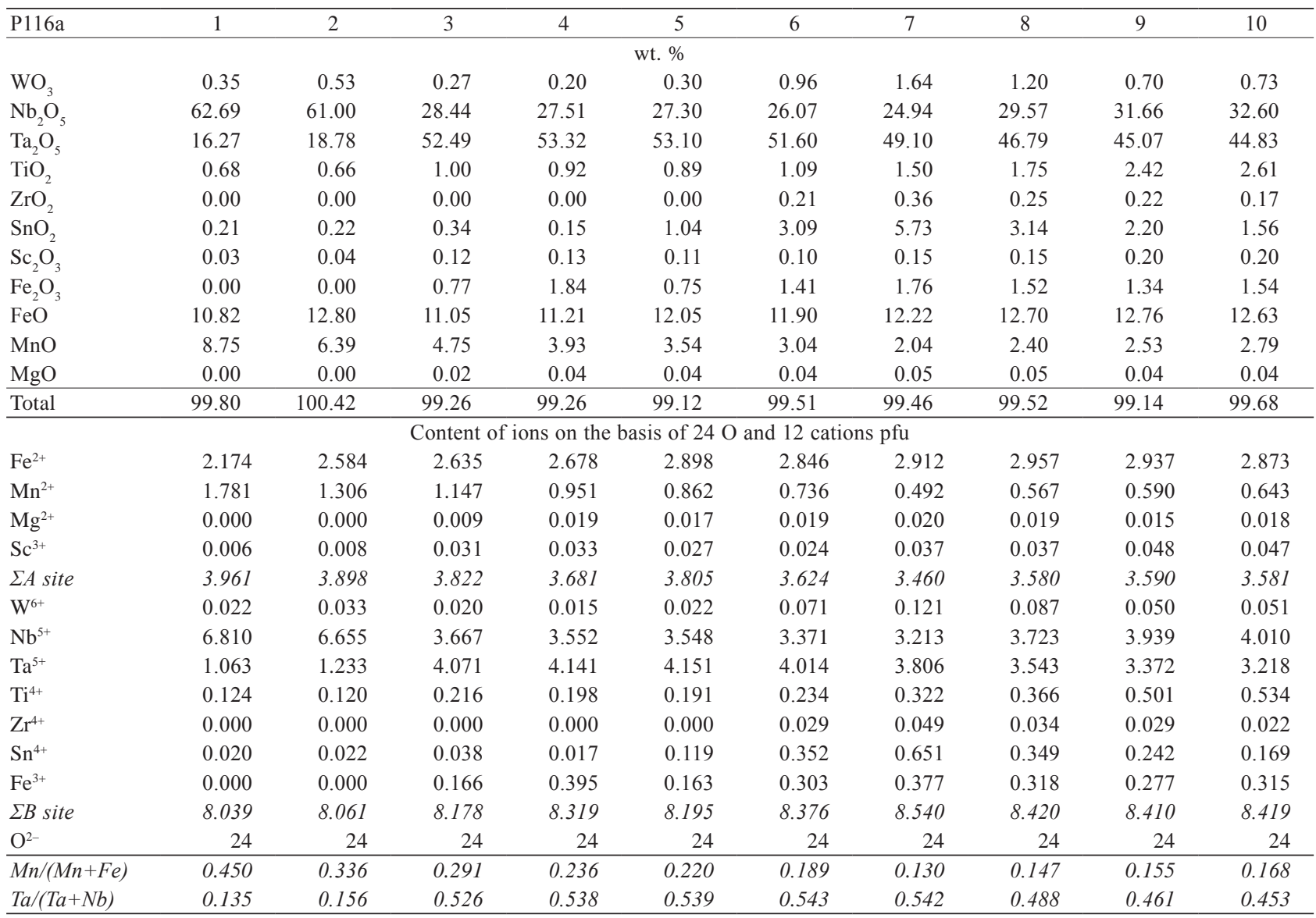

through the blocky feldspar zone up to the quartz core, commonly in association with beryl, tourmaline and garnet, sometimes also with small crystals of zircon, titanite, cheralite, thorite and even with samarskite-group minerals and fergusonite-(Y). They form single, steel blue to black euhedral crystals ranging from needle-like forms to plates up to $7 \mathrm{~cm}$ long and $1 \mathrm{~cm}$ wide. The crystals are often randomly intergrown, and sometimes form rosettes (to 3-4 cm across) or string-like intergrowths up to $10 \mathrm{~cm}$ long. Many crystals of columbite-(Fe) show simple compositional growth-zoning visible in backscattered-electron (BSE) images as a distinct dark-grey core overgrown by a lighter mantle (Figs $2 \mathrm{a}-\mathrm{b}$ ). Both the core and the mantle show second order oscillatory zoning resulting from subtle variations in $\mathrm{Mn}$ and Fe contents. This style of zoning is typical mainly of crystals showing undisturbed progressive $\mathrm{Mn}-\mathrm{Fe}$ and $\mathrm{Ta}-\mathrm{Nb}$ core-to-rim fractionation. Similar zoning in crystals obtained from the external portion of the blocky feldspar zone and associated with zircon, monazite, thorite and fergusonite-(Y) reflects the reversed $\mathrm{Mn}-\mathrm{Fe}$ fractionation coupled with a very limited, progressive $\mathrm{Ta}-\mathrm{Nb}$ fractionation. A more complex zoning pattern involving a few concentric bands with blurred boundaries, is less common (right part of a crystal in Fig. 2c). Crystals with such an internal texture can be overgrown by, or partly replaced with, younger CGM evolving to tantalite-(Fe) with a higher $\mathrm{Ta} /(\mathrm{Nb}+$ $\mathrm{Ta})$ value (the lightest regions of crystals in Figs $2 \mathrm{~b}-\mathrm{e}$ ). The latter seldom displays compositional variations in the final growth stage (Fig. 2f, inserts $\mathrm{fl}$ and $\mathrm{f} 2$ ). None of the columbite crystals seen was intergrown with ilmenitegroup minerals and intergrowths with cassiterite were only occasionally found.

Three different Mn-Fe vs. Ta-Nb fractionation paths reflected in single crystal core-to-rim zoning were distinguished on the basis of columbite crystals collected from different places in the blocky feldspar zone of a few veins with similar mineralogical and geochemical signatures (Fig. 3). They indicate that CGM evolution began with the crystallization of columbite- $(\mathrm{Fe})$ at $\mathrm{Mn} /(\mathrm{Mn}+\mathrm{Fe})$ close to $0.34-0.36$ and $\mathrm{Ta} /(\mathrm{Ta}+\mathrm{Nb})$ to $0.05-0.07$ along a normal fractionation path towards columbite-(Mn) (trend I in Figs $3 \mathrm{a}-\mathrm{b})$. The highest $\mathrm{Mn} /(\mathrm{Mn}+\mathrm{Fe})$ values slightly exceed 0.50 . The $\mathrm{Mn}-\mathrm{Fe}$ fractionation becomes subsequently reversed down to a $\mathrm{Mn} /(\mathrm{Mn}+\mathrm{Fe})$ value a little below 0.20 . The reversal takes place over a broad range of $\mathrm{Ta} /(\mathrm{Ta}+\mathrm{Nb})$ values from 0.09 to 0.27 , which probably reflects the various positions of the crystals 

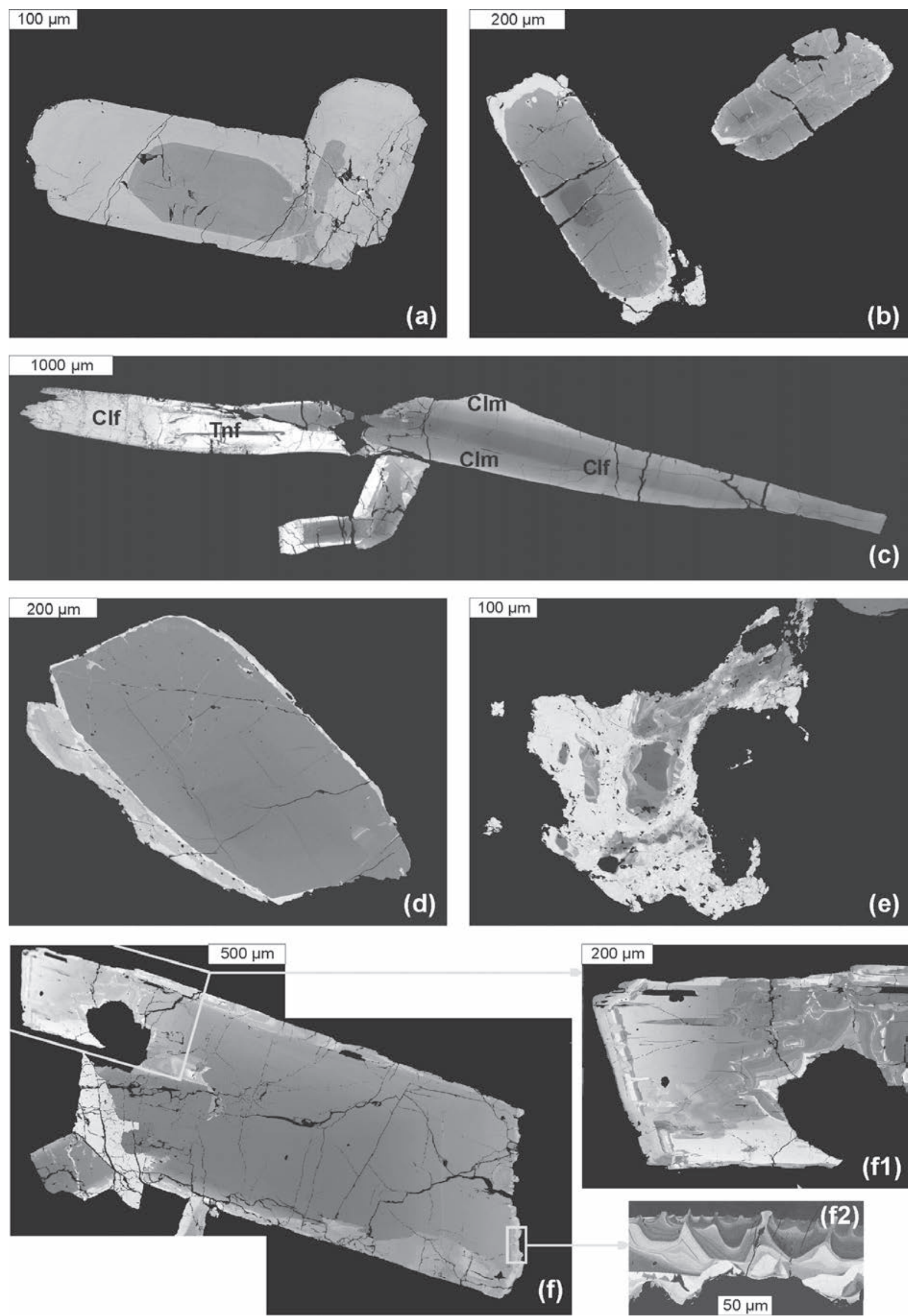
(Fe,Mn)-(Ti,Sn)-(Nb, Ta) oxide assemblage in the mixed pegmatite from the Sowie Mts block, Poland

Tab. 1b Representative compositions of a columbite crystal of fractionation style I+IIb

\begin{tabular}{|c|c|c|c|c|c|c|c|c|c|c|c|c|c|c|c|}
\hline P114a & 1 & 2 & 3 & 4 & 5 & 6 & 7 & 8 & 9 & 10 & 11 & 12 & 13 & 14 & 15 \\
\hline \multicolumn{16}{|c|}{ wt. \% } \\
\hline $\mathrm{WO}_{3}$ & 0.58 & 0.40 & 0.28 & 0.46 & 0.48 & 0.55 & 0.46 & 0.42 & 0.07 & 0.43 & 0.42 & 0.45 & 0.15 & 0.31 & 0.28 \\
\hline $\mathrm{Nb}_{2} \mathrm{O}_{5}$ & 64.13 & 62.51 & 59.08 & 55.76 & 53.16 & 49.64 & 47.40 & 44.35 & 40.51 & 37.89 & 33.90 & 30.46 & 27.64 & 27.42 & 29.74 \\
\hline $\mathrm{Ta}_{2} \mathrm{O}_{5}$ & 15.85 & 17.41 & 21.17 & 24.28 & 26.49 & 30.16 & 32.90 & 35.97 & 40.75 & 42.94 & 47.14 & 51.34 & 54.21 & 54.01 & 51.65 \\
\hline $\mathrm{TiO}_{2}$ & 0.72 & 0.73 & 0.65 & 0.68 & 0.75 & 0.72 & 0.61 & 0.62 & 0.89 & 0.78 & 0.66 & 0.69 & 0.46 & 0.72 & 0.87 \\
\hline $\mathrm{ZrO}_{2}$ & 0.00 & 0.00 & 0.00 & 0.12 & 0.10 & 0.17 & 0.14 & 0.12 & 0.14 & 0.17 & 0.15 & 0.00 & 0.00 & 0.00 & 0.00 \\
\hline $\mathrm{SnO}_{2}$ & 0.18 & 0.27 & 0.24 & 0.29 & 0.33 & 0.32 & 0.27 & 0.40 & 0.36 & 0.40 & 0.45 & 0.40 & 0.18 & 0.29 & 0.39 \\
\hline $\mathrm{Sc}_{2} \mathrm{O}_{3}$ & 0.00 & 0.04 & 0.03 & 0.05 & 0.06 & 0.06 & 0.06 & 0.06 & 0.09 & 0.07 & 0.12 & 0.10 & 0.14 & 0.12 & 0.11 \\
\hline $\mathrm{Fe}_{2} \mathrm{O}_{3}$ & 0.00 & 0.00 & 0.00 & 0.00 & 0.00 & 0.00 & 0.00 & 0.15 & 0.00 & 0.00 & 0.15 & 0.00 & 0.50 & 0.47 & 0.97 \\
\hline $\mathrm{FeO}$ & 9.84 & 9.66 & 9.30 & 9.05 & 9.01 & 8.88 & 8.94 & 8.79 & 8.84 & 9.01 & 9.10 & 9.43 & 9.45 & 10.44 & 11.40 \\
\hline $\mathrm{MnO}$ & 8.95 & 9.38 & 9.48 & 9.47 & 9.27 & 8.99 & 9.09 & 8.96 & 8.21 & 8.18 & 7.63 & 7.08 & 6.50 & 5.51 & 4.52 \\
\hline $\mathrm{MgO}$ & 0.00 & 0.00 & 0.00 & 0.00 & 0.00 & 0.00 & 0.00 & 0.00 & 0.00 & 0.00 & 0.00 & 0.00 & 0.00 & 0.00 & 0.03 \\
\hline Total & 100.26 & 100.40 & 100.23 & 100.16 & 99.65 & 99.49 & 99.87 & 99.85 & 99.86 & 99.86 & 99.71 & 99.95 & 99.23 & 99.28 & 99.96 \\
\hline \multicolumn{16}{|c|}{ Content of ions on the basis of $24 \mathrm{O}$ and 12 cations pfu } \\
\hline $\mathrm{Fe}^{2+}$ & 1.961 & 1.935 & 1.896 & 1.875 & 1.896 & 1.904 & 1.933 & 1.929 & 1.976 & 2.042 & 2.110 & 2.226 & 2.279 & 2.513 & 2.685 \\
\hline $\mathrm{Mn}^{2+}$ & 1.806 & 1.903 & 1.959 & 1.987 & 1.976 & 1.950 & 1.991 & 1.991 & 1.860 & 1.877 & 1.792 & 1.693 & 1.589 & 1.343 & 1.078 \\
\hline $\mathrm{Mg}^{2+}$ & 0.000 & 0.000 & 0.000 & 0.000 & 0.000 & 0.000 & 0.000 & 0.000 & 0.000 & 0.000 & 0.000 & 0.000 & 0.000 & 0.000 & 0.011 \\
\hline $\mathrm{Sc}^{3+}$ & 0,000 & 0,009 & 0,007 & 0,011 & 0,012 & 0,014 & 0,014 & 0,015 & 0,021 & 0,018 & 0,029 & 0,025 & 0,035 & 0,031 & 0,028 \\
\hline$\Sigma A$ & 3.767 & 3.847 & 3.862 & 3.873 & 3.884 & 3.868 & 3.937 & 3.935 & 3.856 & 3.937 & 3.930 & 3.943 & 3.903 & 3.888 & 3.803 \\
\hline $\mathrm{W}^{6+}$ & 0.036 & 0.025 & 0.018 & 0.029 & 0.031 & 0.037 & 0.031 & 0.029 & 0.005 & 0.030 & 0.030 & 0.033 & 0.011 & 0.023 & 0.021 \\
\hline $\mathrm{Nb}^{5+}$ & 1.027 & 1.134 & 1.404 & 1.635 & 1.812 & 2.102 & 2.313 & 2.566 & 2.963 & 3.164 & 3.553 & 3.940 & 4.252 & 4.229 & 3.956 \\
\hline $\mathrm{Ta}^{5+}$ & 6.906 & 6.769 & 6.514 & 6.243 & 6.045 & 5.750 & 5.541 & 5.261 & 4.896 & 4.642 & 4.248 & 3.885 & 3.605 & 3.570 & 3.787 \\
\hline $\mathrm{Ti}^{4+}$ & 0.129 & 0.131 & 0.119 & 0.127 & 0.141 & 0.138 & 0.118 & 0.123 & 0.178 & 0.158 & 0.138 & 0.146 & 0.099 & 0.155 & 0.185 \\
\hline $\mathrm{Zr}^{4+}$ & 0.000 & 0.000 & 0.000 & 0.015 & 0.013 & 0.022 & 0.018 & 0.015 & 0.019 & 0.022 & 0.020 & 0.000 & 0.000 & 0.000 & 0.000 \\
\hline $\mathrm{Sn}^{4+}$ & 0.017 & 0.026 & 0.023 & 0.028 & 0.033 & 0.033 & 0.028 & 0.042 & 0.038 & 0.044 & 0.049 & 0.045 & 0.021 & 0.033 & 0.043 \\
\hline $\mathrm{Fe}^{3+}$ & 0,000 & 0,000 & 0,000 & 0,000 & 0,000 & 0,000 & 0,000 & 0,029 & 0,000 & 0,000 & 0,031 & 0,000 & 0,108 & 0,101 & 0,206 \\
\hline$\Sigma B$ & 8.115 & 8.086 & 8.079 & 8.077 & 8.075 & 8.081 & 8.049 & 8.065 & 8.099 & 8.061 & 8.070 & 8.049 & 8.097 & 8.112 & 8.197 \\
\hline $\mathrm{O}^{2-}$ & 24 & 24 & 24 & 24 & 24 & 24 & 24 & 24 & 24 & 24 & 24 & 24 & 24 & 24 & 24 \\
\hline $\mathrm{Mn} /(\mathrm{Mn}+\mathrm{Fe})$ & 0.479 & 0.496 & 0.508 & 0.515 & 0.510 & 0.506 & 0.507 & 0.504 & 0.485 & 0.479 & 0.456 & 0.432 & 0.400 & 0.339 & 0.272 \\
\hline$T a /(T a+N b)$ & 0.129 & 0.144 & 0.177 & 0.208 & 0.231 & 0.268 & 0.295 & 0.328 & 0.377 & 0.405 & 0.455 & 0.503 & 0.541 & 0.542 & 0.511 \\
\hline
\end{tabular}

within the blocky feldspar zone. It is usually coupled with a sudden decrease in the $\mathrm{Mn} /(\mathrm{Mn}+\mathrm{Fe})$ ratio at almost constant $\mathrm{Ta} /(\mathrm{Ta}+\mathrm{Nb})$ values (trend IIa in Fig. 3a) and occasionally with a distinct progressive decrease in $\mathrm{Mn} /$ $(\mathrm{Mn}+\mathrm{Fe})$ at increasing $\mathrm{Ta} /(\mathrm{Ta}+\mathrm{Nb})$ values (trend $\mathrm{IIb}$ in Fig. 3b). Columbite-group minerals that occur together with zircon, monazite, thorite and fergusonite close to the border of the graphic and blocky feldspar zones display only a slight progressive $\mathrm{Mn}-\mathrm{Fe}$ fractionation as well as Ta increase during the reversed Mn-Fe fractionation.

Fig. 2 Back-scattered electron (BSE) images of columbite-group minerals: a - a two-zone crystal of columbite-(Fe) of fractionation style IIc (P123d specimen); b - a crystal of columbite-(Fe) overgrown by younger columbite-(Fe) with higher Ta, fractionation style IIa (P121c specimen); c - a crystal of columbite-(Fe) evolving progressively to columbite-(Mn), intergrown with tantalite-(Fe) evolving to columbite-(Fe); fractionation style IIa (P41 specimen); d - a crystal of columbite-(Fe) overgrown by younger, heterogeneous columbite-( $\mathrm{Fe})$ with higher Ta; fractionation style IIa (P117 specimen); e - replacement of columbite-(Fe) by younger columbite-( $\mathrm{Fe})$ with higher Ta; fractionation style IIa (P118b specimen); $\mathbf{f}$ - a crystal of columbite-(Fe) evolving progressively to tantalite-(Fe); fractionation style IIb (P114a specimen); inserts $\mathrm{f} 1$ and $\mathrm{f} 2$ present details of compositional heterogeneity that indicates oscillations in $\mathrm{Mn}-\mathrm{Fe}$ and $\mathrm{Ta}-\mathrm{Nb}$ activities. Abbreviations: Clf - columbite-(Fe), Clm - columbite-(Mn), Tnf - tantalite-(Fe).
Nonetheless, the reversed Mn-Fe fractionation attains almost the same degree (trend IIc in Fig. 3c) as in crystals showing trends IIa and IIb.

The progressive Mn-Fe fractionation of trend $\mathrm{I}$ is typically connected with decreasing $\mathrm{Fe}$, Ti, Sn and Sc contents in columbite growing under reducing conditions $\left(\mathrm{Fe}^{3+} / \mathrm{Fe}_{\text {total }} \approx 0\right)$. The nature of the reversed fractionation trends IIa-c results from the opposite tendencies, with distinct enrichment in $\mathrm{Ti}, \mathrm{Sn}, \mathrm{Sc}$ and sometimes also $\mathrm{Zr}$ and $\mathrm{Fe}$ under increasing $\mathrm{Fe}^{3+} /$ $\mathrm{Fe}_{\text {total }}$ ratios, especially at the final stages of crystallization (Tabs 1a-c). Generally, many CGM with $\mathrm{Mn} /$ $(\mathrm{Mn}+\mathrm{Fe})$ ratios below $\sim 0.35$, and thus related to the final stages of the reversed Mn-Fe fractionation, show distinct enrichment in $\mathrm{Ti}$, and sometimes also Sc, followed by higher Sn values (Fig. 4). Titanium commonly concentrates in the outermost zones of the CGM crystals formed at usually $\mathrm{Mn} /(\mathrm{Mn}+\mathrm{Fe}) \leq$ 0.20 , and sporadically in CGM inclusions occurring in ishikawaite crystals, reaching similar $\mathrm{TiO}_{2}$ contents of c. 3.13 wt. $\%(0.58-0.59$ Ti $a p f u)$. Tin concentrated with, or without, Ti at the final stages of CGM crystallization, reaching the highest $\mathrm{SnO}_{2}$ content, 3.14 wt. $\%(0.35$ Sn apfu), in tantalite-(Fe) (Fig. 2e; Tab. 1a). 

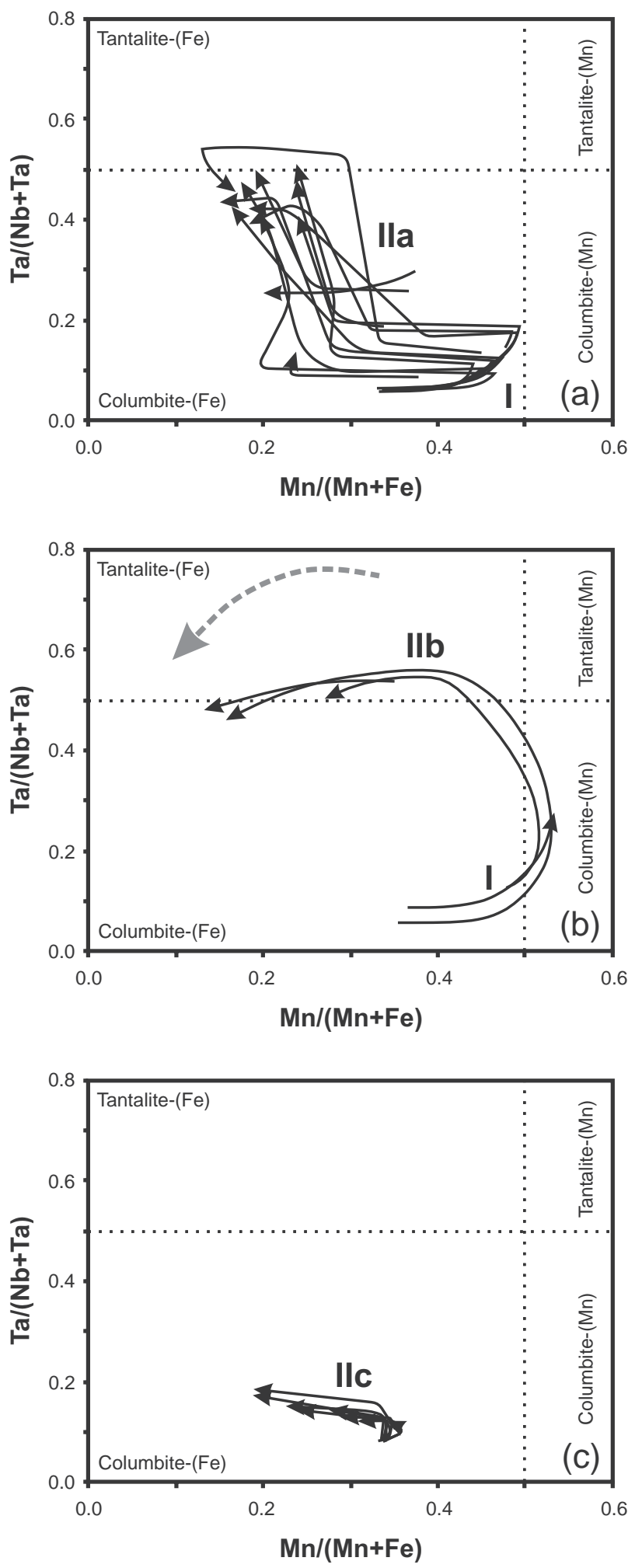

Fig. $3 \mathrm{Ta}-\mathrm{Nb}$ vs. Mn-Fe fractionation paths for CGM in the columbite quadrilateral: a - typical paths with suddenly reversed Mn-Fe fractionation; $\mathbf{b}$ - paths with possibly continuous crystallization with distinct reversed $\mathrm{Mn}-\mathrm{Fe}$ fractionation at increasing $\mathrm{Ta}-\mathrm{Nb}$ fractionation; grey dashed line - fractionation path of ferrowodginite; $\mathbf{c}$ - paths with negligible $\mathrm{Ta}-\mathrm{Nb}$ fractionation at reversed $\mathrm{Mn}-\mathrm{Fe}$ fractionation. I, IIa, IIb and IIc - styles of Ta-Nb vs. Mn-Fe fractionation.
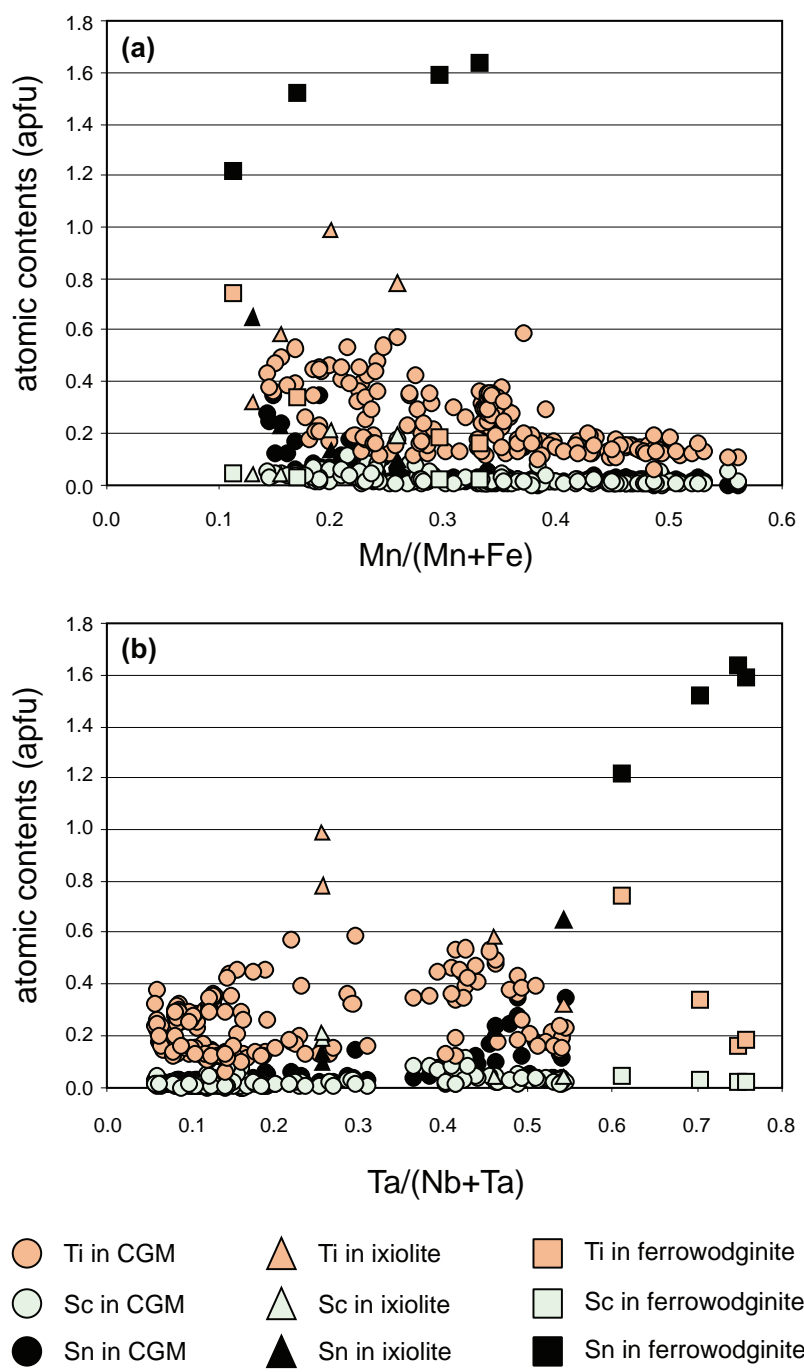

Fig. 4 Binary plots of atomic content of $\mathrm{Ti}, \mathrm{Sc}$ and $\mathrm{Sn}$ vs. $\mathrm{Mn}-\mathrm{Fe}$ fractionation expressed as $\mathrm{Mn} /(\mathrm{Mn}+\mathrm{Fe})$ (a) and $\mathrm{Ta}-\mathrm{Nb}$ fractionation expressed as $\mathrm{Ta} /(\mathrm{Nb}+\mathrm{Ta})(\mathbf{b})$.

Scandium and $\mathrm{Zr}$ are subordinate; both components sometimes concentrate along with Ti. The greatest $\mathrm{Sc}_{2} \mathrm{O}_{3}$ content, 0.85 wt. \% (0.18 Sc apfu), and $\mathrm{ZrO}_{2}$ up to 0.45 wt. $\%(0.05 \mathrm{Zr}$ apfu) were noted in titanian columbite. Finally, it is noteworthy that $\mathrm{Mg}$ is only a subordinate component, occasionally reaching 0.17 $\mathrm{MgO}$ wt. \%, i.e. $0.06 \mathrm{Mg} a p f u$, in the outermost zones of some columbite crystals.

The $(\mathrm{Nb}+\mathrm{Ta}+\mathrm{W})-(\mathrm{Ti}+\mathrm{Sn}+\mathrm{Zr}+\mathrm{Hf})-\left(\mathrm{Fe}_{\text {total }}+\mathrm{Mn}+\right.$ $\mathrm{Mg}+\mathrm{Sc}$ ) ternary diagram (Fig. 5) shows that the compositional trend of CGM runs from columbite-tantalite towards a hypothetical composition of $(\mathrm{Fe}, \mathrm{Mn})_{4}(\mathrm{Ti}, \mathrm{Sn})_{4}(\mathrm{Nb}, \mathrm{Ta})_{4} \mathrm{O}_{24}$, which can be obtained from CGM through the euxenite-type substitution $(\mathrm{Fe}, \mathrm{Mn})^{2+}+(\mathrm{Nb}, \mathrm{Ta})^{5+} \leftrightarrow(\mathrm{Sn}, \mathrm{Fe})^{3+}+(\mathrm{Ti}, \mathrm{Sn})^{4+}$, corroborated by a very strong negative correlation between the totals of $\mathrm{R}^{2+} \mathrm{R}^{5+}$ and $\mathrm{R}^{3+} \mathrm{R}^{4+}$ cations (Fig. 6a). This substitution was suggested for CGM and ixiolite by Novák 
Tab. 1c Representative compositions of a columbite crystal of fractionation style IIc

\begin{tabular}{|c|c|c|c|c|}
\hline P124d & 1 & 2 & 3 & 4 \\
\hline \multicolumn{5}{|c|}{ wt. \% } \\
\hline $\mathrm{WO}_{3}$ & 0.91 & 0.95 & 1.18 & 1.23 \\
\hline $\mathrm{Nb}_{2} \mathrm{O}_{5}$ & 67.23 & 61.09 & 59.64 & 57.95 \\
\hline $\mathrm{Ta}_{2} \mathrm{O}_{5}$ & 9.69 & 14.68 & 17.07 & 17.65 \\
\hline $\mathrm{TiO}_{2}$ & 1.58 & 1.97 & 2.00 & 2.54 \\
\hline $\mathrm{ZrO}_{2}$ & 0.00 & 0.37 & 0.00 & 0.00 \\
\hline $\mathrm{SnO}_{2}$ & 0.21 & 0.37 & 0.32 & 0.31 \\
\hline $\mathrm{Sc}_{2} \mathrm{O}_{3}$ & 0.09 & 0.08 & 0.27 & 0.25 \\
\hline $\mathrm{Fe}_{2} \mathrm{O}_{3}$ & 0.61 & 1.55 & 0.66 & 1.45 \\
\hline $\mathrm{FeO}$ & 12.78 & 11.66 & 13.17 & 13.66 \\
\hline $\mathrm{MnO}$ & 6.74 & 6.64 & 5.46 & 4.28 \\
\hline $\mathrm{MgO}$ & 0.06 & 0.04 & 0.07 & 0.08 \\
\hline Total & 99.90 & 99.41 & 99.85 & 99.40 \\
\hline \multicolumn{5}{|c|}{ Content of ions based on $24 \mathrm{O}$ and 12 cations pfu } \\
\hline $\mathrm{Fe}^{2+}$ & 2.487 & 2.325 & 2.642 & 2.751 \\
\hline $\mathrm{Mn}^{2+}$ & 1.329 & 1.340 & 1.110 & 0.873 \\
\hline $\mathrm{Mg}^{2+}$ & 0.020 & 0.014 & 0.023 & 0.028 \\
\hline $\mathrm{Sc}^{3+}$ & 0.018 & 0.016 & 0.057 & 0.052 \\
\hline$\Sigma A$ & 3.854 & 3.696 & 3.833 & 3.704 \\
\hline $\mathrm{W}^{6+}$ & 0.055 & 0.059 & 0.073 & 0.077 \\
\hline $\mathrm{Nb}^{5+}$ & 7.074 & 6.584 & 6.469 & 6.309 \\
\hline $\mathrm{Ta}^{5+}$ & 0.613 & 0.952 & 1.114 & 1.156 \\
\hline $\mathrm{Ti}^{4+}$ & 0.278 & 0.353 & 0.361 & 0.461 \\
\hline $\mathrm{Zr}^{4+}$ & 0.000 & 0.043 & 0.000 & 0.000 \\
\hline $\mathrm{Sn}^{4+}$ & 0.020 & 0.035 & 0.030 & 0.030 \\
\hline $\mathrm{Fe}^{3+}$ & 0.107 & 0.279 & 0.120 & 0.263 \\
\hline$\Sigma B$ & 8.146 & 8.304 & 8.167 & 8.296 \\
\hline $\mathrm{O}^{2-}$ & 24 & 24 & 24 & 24 \\
\hline$M n /(M n+F e)$ & 0.339 & 0.340 & 0.287 & 0.225 \\
\hline $\mathrm{Ta} /(\mathrm{Ta}+\mathrm{Nb})$ & 0.080 & 0.126 & 0.147 & 0.155 \\
\hline
\end{tabular}

Columbite-(Fe) usually forms the cores of such inclusions, overgrown by thin rims of titanian ixiolite. This succession reflects the progressive euxenite-type substitution that brings three- and four-valent cations into the structure of a Fe- and Nb-bearing orthorhombic phase. Compared to CGM, the ixiolite shows a distinct enrichment in $\mathrm{TiO}_{2}$ (up to 5.33 wt. \%), $\mathrm{Sc}_{2} \mathrm{O}_{3}$ (to 1.0 wt. \%) and rather low contents of $\mathrm{SnO}_{2}\left(1.36\right.$ wt. \%) as well as of calculated $\mathrm{Fe}_{2} \mathrm{O}_{3}$ (1.61 wt. \%) (Tab. 2).

Stannian ixiolite (Fig. 7b) has been found in a grain composed of a relict of columbite-(Fe) with the reversed $\mathrm{Mn}-\mathrm{Fe}$ fractionation of trend IIa. The relict is overgrown by titanian tantalite-(Fe), followed by stannian tantalite(Fe) and again by titanian columbite-(Fe). Such a compositional evolution corresponds to the observation that the Ti enrichment in CGM precedes the increase of Sn. The appearance of titanian columbite-(Fe) at the final stage of crystal growth suggests that the high activity of Sn (5.73 wt. \% of $\mathrm{SnO}_{2}$ in the stannian ixiolite) was rather ephemeral. $\mathrm{TiO}_{2}$ concentrations rise across the crystal from 1.09 wt. $\%$ in the tantalite-(Fe) to 1.50 wt. $\%$ in the stannian ixiolite, and reach $2.61 \mathrm{wt} . \%$ in titanian columbite-(Fe) (Tab. 2). Scandium does not concentrate in the minerals and Čech (1996) with Wise et al. (1998) and confirmed recently by Beurlen et al. (2007).

\subsection{Ixiolite}

Both titanian ixiolite and stannian ixiolite are present in the Julianna pegmatites.

Titanian ixiolite has been found along with titanian columbite-(Fe) as irregular or elongated thin inclusions, up to $200 \mu \mathrm{m}$ long, in crystals of ishikawaite hosted by quartz and associated with microcline, yellowish beryl and zircon, in the outermost part of the massive feldspars zone (Fig. 7a).

Fig. 5 Ternary diagram $(\mathrm{Ti}+\mathrm{Zr}+\mathrm{Sn}+$ $\mathrm{Hf})-(\mathrm{Nb}+\mathrm{Ta}+\mathrm{W})-\left(\mathrm{Fe}_{\text {total }}+\mathrm{Mg}+\right.$ $\mathrm{Mn}+\mathrm{Sc}$ ) with compositions of CGM, ixiolite, ferrowodginite and cassiterite.

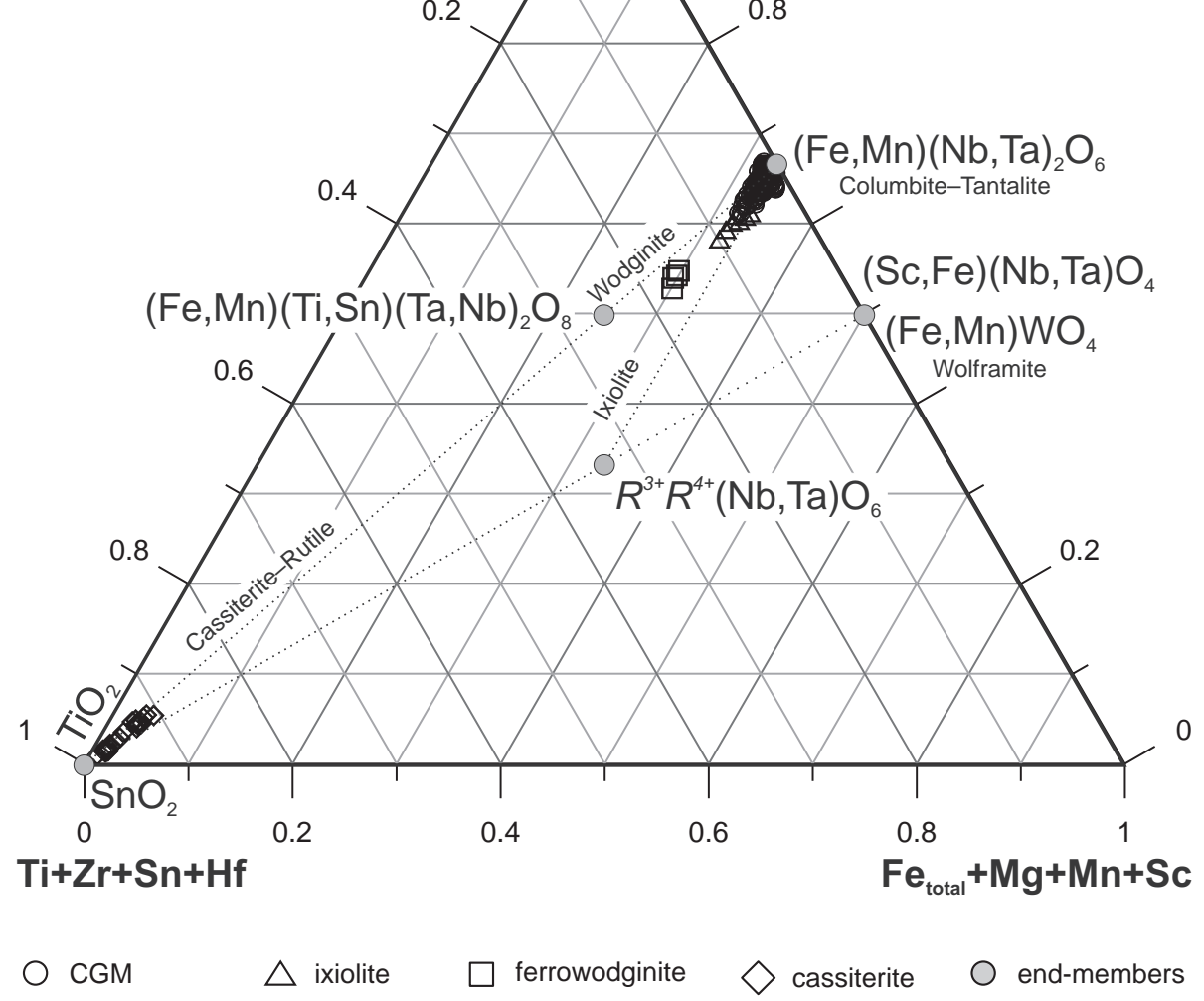



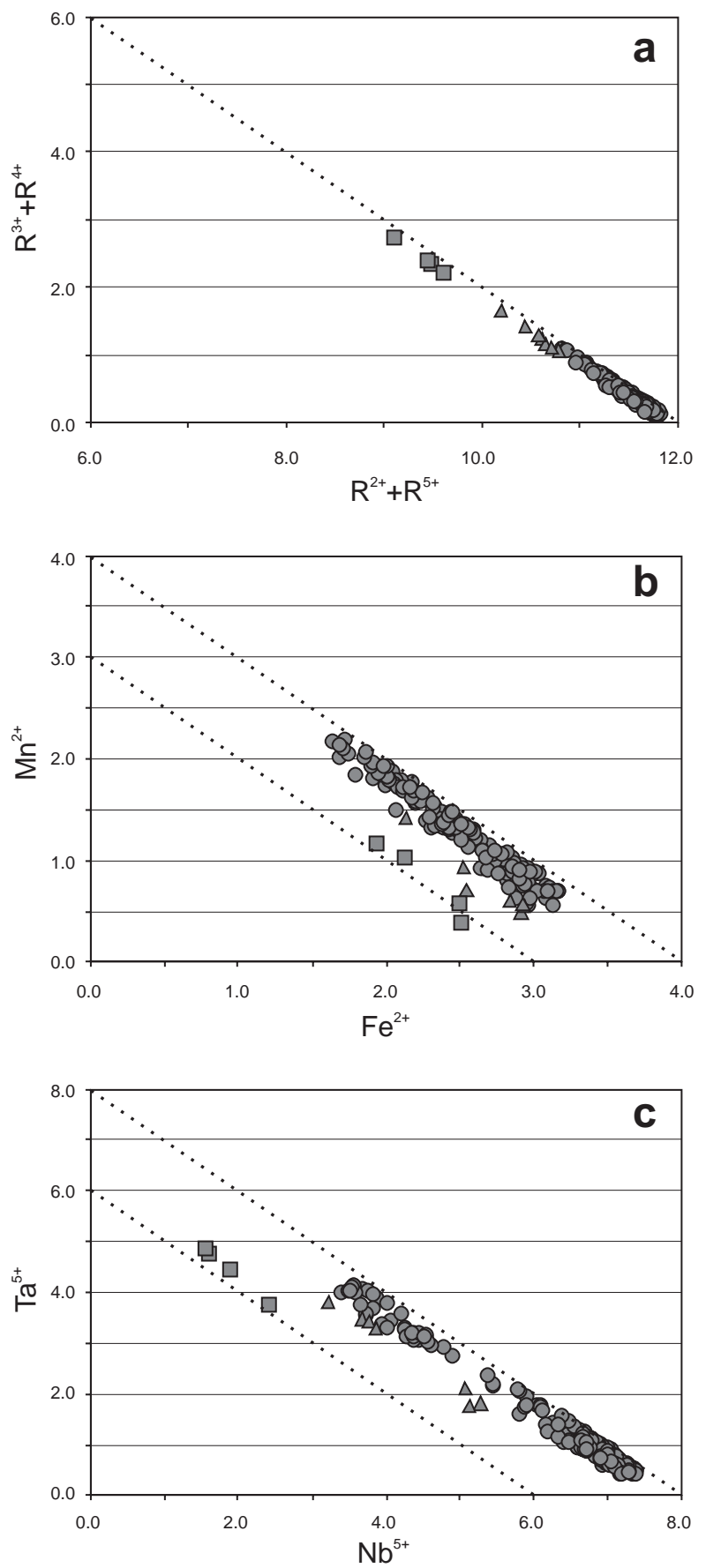

CGM $\triangle$ ixiolite $\square$ ferrowodginite

Fig. 6 Binary plots illustrating compositional relationships in CGM, ixiolite and ferrowodginite: $\mathbf{a}-\Sigma\left(\mathrm{R}^{3+}+\mathrm{R}^{4+}\right)$ vs. $\Sigma\left(\mathrm{R}^{2+}+\mathrm{R}^{5+}\right)$; b $-\mathrm{Mn}^{2+}$ vs. $\mathrm{Fe}^{2+}$; c) $\mathrm{Ta}^{5+}$ vs. $\mathrm{Nb}^{5+}$. Dotted lines $4.0-4.0$ and 3.0-3.0 in (b) and $8.0-8.0$ and 6.0-6.0 in (c) denote the respective amounts of $\mathrm{R}^{2+}$ cations in ideal CGM and ferrowodginite, and $\mathrm{R}^{5+}$ cations in the same end-members, respectively.

forming this grain, whereas the calculated contents of $\mathrm{Fe}^{3+}$ are clearly elevated in the tantalite-(Fe), stannian ixiolite and columbite-(Fe) as well.

\subsection{Ferrowodginite}

One grain of $\mathrm{Nb}$-Ti oxide $2 \mathrm{~mm}$ across contains a zone whose composition corresponds to ferrowodginite. The grain is composed of a crystal of columbite-(Fe) evolving to columbite-(Mn) and finally to tantalite-(Fe), partly corroded and overgrown by ferrowodginite and cassiterite (Fig. 7c; Tab. 2). The highest primary $\mathrm{TiO}_{2}$ concentration found in the columbite-(Fe) core (1.90 wt. \%) decreases along with $\mathrm{Sn}$ and $\mathrm{Sc}$ contents, finally reaching $\sim 0.7 \mathrm{wt} . \%$ $\mathrm{TiO}_{2}$ and $\sim 0.3$ wt. $\% \mathrm{SnO}_{2}$ in the outermost zone. On the other hand, Ta increases, relative to $\mathrm{Nb}$, from $\mathrm{Ta} /(\mathrm{Ta}+\mathrm{Nb})$ $=0.06$ up to 0.54 at decreasing $\mathrm{Mn} /(\mathrm{Mn}+\mathrm{Fe})$ ratios in the outermost zones of the columbite core. A younger titanian tantalite-(Fe) that, along with ferrowodginite, overgrows the columbite core of the grain shows $\mathrm{TiO}_{2}$ and $\mathrm{SnO}_{2}$ contents a magnitude higher, ranging from 1.1-1.2 wt. \% to slightly less than 2.0 wt. \% at almost the same $\mathrm{Ta} /(\mathrm{Ta}+\mathrm{Nb})$ values. Ferrowodginite that co-crystallized with the tantalite shows progressively increasing $\mathrm{TiO}_{2}$, reaching $3.49 \mathrm{wt} . \%$ at an almost constant $\mathrm{SnO}_{2}$ content of 13.0 wt. $\%$ and $\mathrm{Sn} /(\mathrm{Sn}+$ $\mathrm{Ti})$ and $\mathrm{Ta} /(\mathrm{Ta}+\mathrm{Nb})$ ratios decreasing from 0.91 to 0.82 and from 0.76 to 0.70 , respectively. In the outermost zone, $\mathrm{SnO}_{2}$ falls to 10.8 wt. \% and the ratios to $0.61-0.62$. The latest generation of ferrowodginite is overgrown by cassiterite, and in places contains small exsolutions of titanian ixiolite, with still more decreased $\mathrm{Sn} /(\mathrm{Sn}+\mathrm{Ti})$ ratio down to 0.43 in the last mineral. The $\mathrm{Mn}-\mathrm{Fe}$ and $\mathrm{Ta}-\mathrm{Nb}$ fractionation path for the ferrowoodginite is almost parallel to that of tantalite-(Fe) evolving to titanian ixiolite (Fig. 3b). In the successive zones, the composition of ferrowodginite changes from: $\left(\mathrm{Fe}^{2+}{ }_{0.64} \mathrm{Mn}_{0.39}\right)_{\Sigma=1.03}\left(\mathrm{Sn}_{0.55} \mathrm{Ta}_{0.17} \mathrm{Fe}^{3+}{ }_{0.15} \mathrm{Ti}_{0.06}\right.$ $\left.\mathrm{Zr}_{0.03} \mathrm{Sc}_{0.01}\right)_{\Sigma=0.97}\left(\mathrm{Ta}_{1.42} \mathrm{Nb}_{0.53} \mathrm{~W}_{0.05}\right)_{\Sigma=2.00} \mathrm{O}_{8}$ through: $\left(\mathrm{Fe}^{2+}{ }_{0.71} \mathrm{Mn}_{0.35}\right)_{\Sigma=1.06}\left(\mathrm{Sn}_{0.53} \mathrm{Ta}_{0.19} \mathrm{Fe}^{3+}{ }_{0.12} \mathrm{Ti}_{0.06} \mathrm{Zr}_{0.02}\right.$ $\left.\mathrm{Sc}_{0.01}\right)_{\Sigma=0.94}\left(\mathrm{Ta}_{1.43} \mathrm{Nb}_{0.52} \mathrm{~W}_{0.05}\right)_{\Sigma=2.00} \mathrm{O}_{8}$ to $\left(\mathrm{Fe}^{2+}{ }_{0.83} \mathrm{Mn}_{0.20}\right)_{\Sigma=1.03}$ $\left(\mathrm{Sn}_{0.51} \mathrm{Ti}_{0.17} \mathrm{Fe}^{3+}{ }_{0.14} \mathrm{Ta}_{0.11} \mathrm{Zr}_{0.03} \mathrm{Sc}_{0.01}\right)_{\Sigma=0.97}\left(\mathrm{Ta}_{1.32} \mathrm{Nb}_{0.63}\right.$ $\left.\mathrm{W}_{0.05}\right)_{\Sigma=2.00} \mathrm{O}_{8}$, and finally to $\left(\mathrm{Fe}^{2+}{ }_{0.83} \mathrm{Mn}_{0.13}\right)_{\Sigma=0.97}\left(\mathrm{Sn}_{0.41} \mathrm{Ti}_{0.25}\right.$ $\left.\mathrm{Fe}^{3+}{ }_{0.22} \mathrm{Ta}_{0.11} \mathrm{Zr}_{0.02} \mathrm{Sc}_{0.02}\right)_{\Sigma=1.03}\left(\mathrm{Ta}_{1.14} \mathrm{Nb}_{0.81} \mathrm{~W}_{0.05}\right)_{\Sigma=2.00} \mathrm{O}_{8}$, with distinct increase in $\mathrm{Nb}, \mathrm{Ti}^{-\mathrm{Fe}^{3+}}$ and $\mathrm{Fe}^{2+}$ and decrease in $\mathrm{Ta}$, Sn and Mn. Titanium correlates negatively with Sn (Fig. 4b). The contents of $\mathrm{R}^{2+}\left(\mathrm{Fe}^{2+}, \mathrm{Mn}^{2+}\right)$ and $\mathrm{R}^{5+}\left(\mathrm{Ta}^{5+}, \mathrm{Nb}^{5+}\right)$ cations (3.0 and $6.0 \mathrm{apfu}$, respectively) are distinctly lower than in the associated columbite-tantalite and ixiolite crystals, being consistent with the formula of ferrowodginite (Figs $6 b-c$ ).

\subsection{Pyrochlore-supergroup minerals}

Pyrochlore-supergroup minerals are rarely found as alteration products covering or penetrating crystals of CGM, ixiolite and ferrowodginite (Figs 7c-e). They are represented by hydroxy- or keno-microlite with $\mathrm{Ta} /(\mathrm{Ta}+$ $\mathrm{Nb})=0.78$, and more frequently by zero-valent-dominant microlite with $\mathrm{Ta} /(\mathrm{Ta}+\mathrm{Nb}) \approx 0.80-0.70, \mathrm{~Pb}$-enriched zero-valent-dominant microlite with $\mathrm{Ta} /(\mathrm{Ta}+\mathrm{Nb}) \approx$ 

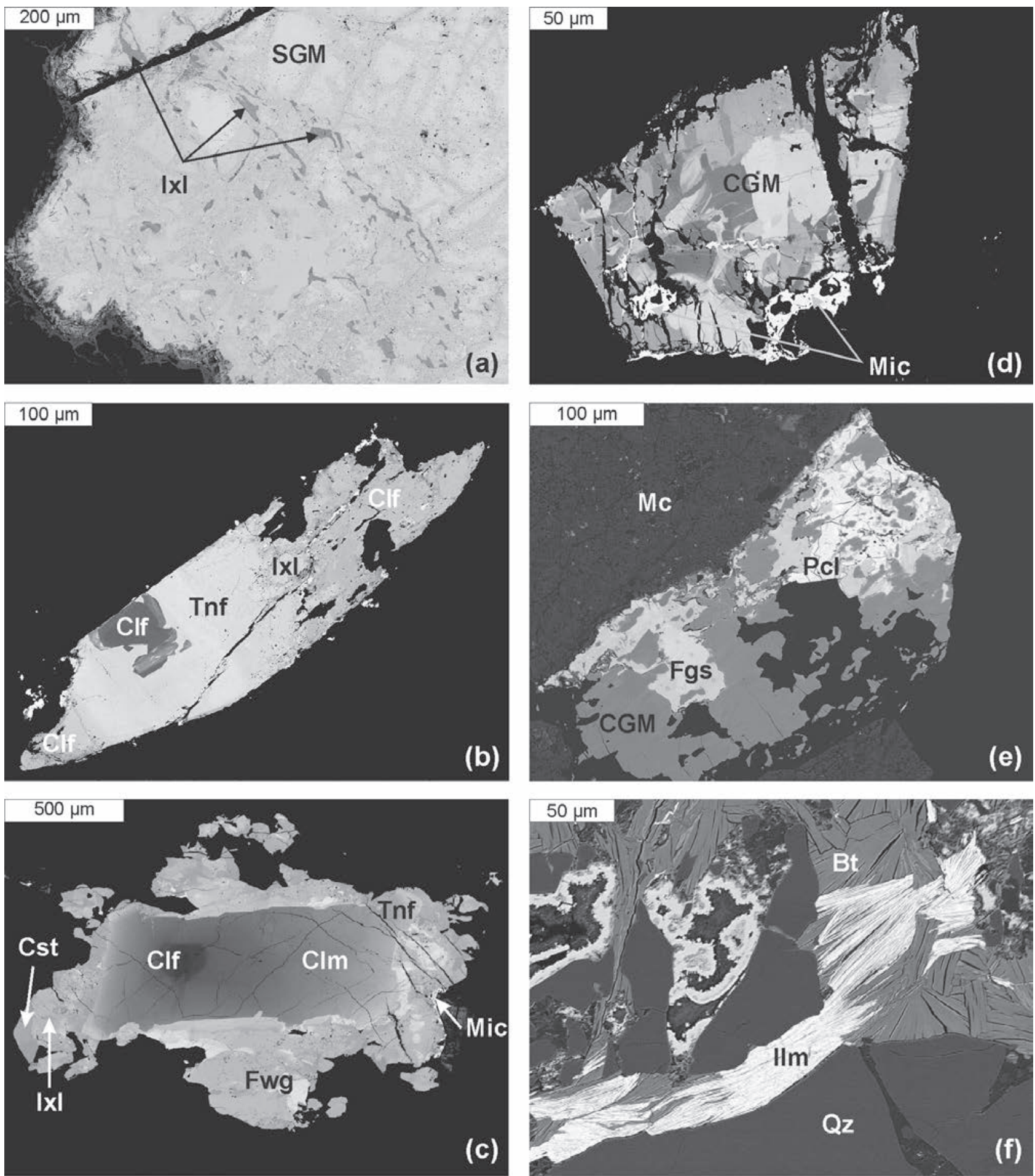

Fig. 7 Back-scattered electron (BSE) images: a - relics of titanian ixiolite in ishikawaite (P7 specimen); $\mathbf{b}$ - columbite-(Fe) replaced by titanian tantalite-(Fe) and stannian ixiolite (P116a specimen); c - a crystal of columbite-(Fe)-columbite-(Mn)-tantalite-(Fe) replaced by ferrowodginite and cassiterite (P13 specimen); d - microlite replacing columbite-group minerals (P119 specimen); $\mathbf{e}$ - Bi-rich pyrochlore associated with columbite(Fe)-columbite-(Mn) and fergusonite-(Y) (P123 specimen); f - zincian ilmenite (P115 specimen). Abbreviations: Bt - biotite, Clf - columbite-(Fe), Clm - columbite-(Mn), CGM - columbite-group minerals, Cst - cassiterite, Fgs - fergusonite, Fwg - ferrowodginite, Ilm - ilmenite, Ixl - ixiolite, $\mathrm{Mc}$ - microcline, Mic - microlite, Pcl - pyrochlore, Qz - quartz, SGM - samarskite-group minerals, Tnf - tantalite-( $\mathrm{Fe})$.

0.88-0.68, Bi-enriched zero-valent-dominant pyrochlore with $\mathrm{Ta} /(\mathrm{Ta}+\mathrm{Nb})=0.42$, and hydroxy- or keno-, Bi-rich pyrochlore with the ratio ranging from 0.17 to 0.07 ; the $\mathrm{Mn} /(\mathrm{Mn}+\mathrm{Fe})$ ratio is always close to zero (Tab. 3). The 
Tab. 2 Representative compositions of ixiolite and ferrowodginite

\begin{tabular}{|c|c|c|c|c|c|c|c|c|c|c|}
\hline & $\begin{array}{c}\mathrm{P} 7 / 1 \\
\mathrm{Ixl}\end{array}$ & $\begin{array}{c}\mathrm{P} 7 / 2 \\
\mathrm{Ixl}\end{array}$ & $\begin{array}{c}\mathrm{P} 7 / 3 \\
\mathrm{Ixl}\end{array}$ & $\begin{array}{c}\mathrm{P} 13 / 10 \\
\text { Ixl }\end{array}$ & $\begin{array}{c}\mathrm{P} 41 / 13 \\
\mathrm{Ixl}\end{array}$ & $\begin{array}{c}\text { P116a } \\
\text { Ixl }\end{array}$ & $\begin{array}{c}\text { P13/11 } \\
\text { Fwg }\end{array}$ & $\begin{array}{c}\text { P13/12 } \\
\text { Fwg }\end{array}$ & $\begin{array}{c}\text { P13/13 } \\
\text { Fwg }\end{array}$ & $\begin{array}{c}\text { P13/14 } \\
\text { Fwg }\end{array}$ \\
\hline \multicolumn{11}{|c|}{ wt. \% } \\
\hline $\mathrm{WO}_{3}$ & 2.16 & 2.20 & 1.99 & 1.78 & 2.39 & 1.64 & 1.98 & 1.98 & 2.02 & 2.25 \\
\hline $\mathrm{Nb}_{2} \mathrm{O}_{5}$ & 44.45 & 47.23 & 46.04 & 31.39 & 29.20 & 24.94 & 11.56 & 11.18 & 13.89 & 18.81 \\
\hline $\mathrm{Ta}_{2} \mathrm{O}_{5}$ & 30.92 & 27.07 & 26.25 & 44.31 & 45.96 & 49.10 & 57.30 & 58.11 & 56.64 & 48.78 \\
\hline $\mathrm{TiO}_{2}$ & 3.13 & 4.21 & 5.33 & 2.85 & 2.07 & 1.50 & 0.73 & 0.80 & 1.51 & 3.49 \\
\hline $\mathrm{SnO}_{2}$ & 1.50 & 0.93 & 1.36 & 2.07 & 2.50 & 5.73 & 13.46 & 12.98 & 12.74 & 10.80 \\
\hline $\mathrm{Sc}_{2} \mathrm{O}_{3}$ & 0.06 & 0.89 & 1.00 & 0.16 & 0.22 & 0.15 & 0.09 & 0.08 & 0.11 & 0.19 \\
\hline $\mathrm{Fe}_{2} \mathrm{O}_{3}$ & 1.38 & 0.79 & 1.61 & 2.16 & 1.96 & 1.76 & 1.94 & 1.60 & 1.90 & 3.08 \\
\hline $\mathrm{FeO}$ & 10.12 & 12.21 & 12.34 & 12.48 & 12.62 & 12.22 & 7.53 & 8.24 & 9.91 & 10.51 \\
\hline $\mathrm{MnO}$ & 6.62 & 4.46 & 3.39 & 2.62 & 2.34 & 2.04 & 4.54 & 4.00 & 2.34 & 1.65 \\
\hline $\mathrm{MgO}$ & 0.13 & 0.17 & 0.17 & 0.03 & 0.06 & 0.05 & 0.00 & 0.02 & 0.04 & 0.02 \\
\hline Total & 100.93 & 100.41 & 99.77 & 99.85 & 99.34 & 99.46 & 99.69 & 99.38 & 99.72 & 100.07 \\
\hline $\mathrm{W}^{6+}$ & 0.141 & 0.141 & 0.127 & 0.126 & 0.172 & 0.121 & 0.157 & 0.158 & 0.157 & 0.166 \\
\hline $\mathrm{Nb}^{5+}$ & 5.067 & 5.277 & 5.129 & 3.858 & 3.668 & 3.213 & 1.600 & 1.558 & 1.882 & 2.417 \\
\hline $\mathrm{Ta}^{5+}$ & 2.120 & 1.819 & 1.759 & 3.276 & 3.473 & 3.806 & 4.771 & 4.873 & 4.454 & 3.770 \\
\hline $\mathrm{Ti}^{4+}$ & 0.594 & 0.783 & 0.989 & 0.584 & 0.433 & 0.322 & 0.167 & 0.186 & 0.341 & 0.746 \\
\hline $\mathrm{Zr}^{4+}$ & 0.055 & 0.030 & 0.036 & 0.000 & 0.000 & 0.049 & 0.084 & 0.059 & 0.089 & 0.065 \\
\hline $\mathrm{Sn}^{4+}$ & 0.151 & 0.092 & 0.133 & 0.442 & 0.277 & 0.651 & 1.643 & 1.595 & 1.522 & 1.224 \\
\hline $\mathrm{Sc}^{3+}$ & 0.013 & 0.192 & 0.214 & 0.039 & 0.054 & 0.037 & 0.025 & 0.023 & 0.029 & 0.046 \\
\hline $\mathrm{Fe}^{3+}$ & 0.262 & 0.147 & 0.299 & 0.225 & 0.410 & 0.377 & 0.448 & 0.372 & 0.429 & 0.660 \\
\hline $\mathrm{Fe}^{2+}$ & 2.134 & 2.524 & 2.542 & 2.837 & 2.931 & 2.912 & 1,929 & 2.125 & 2.485 & 2.499 \\
\hline $\mathrm{Mn}^{2+}$ & 1.413 & 0.933 & 0.708 & 0.604 & 0.555 & 0.492 & 1.177 & 1.044 & 0.595 & 0.397 \\
\hline $\mathrm{Mg}^{2+}$ & 0.051 & 0.062 & 0.064 & 0.011 & 0.025 & 0.020 & 0.000 & 0.008 & 0.016 & 0.010 \\
\hline$\Sigma$ cations & 12.000 & 12.000 & 12.000 & 12.000 & 12.000 & 12.000 & 12.000 & 12.000 & 12.000 & 12.000 \\
\hline $\mathrm{O}^{2-}$ & 24 & 24 & 24 & 24 & 24 & 24 & 24 & 24 & 24 & 24 \\
\hline
\end{tabular}

Abbreviations: Ixl - ixiolite, Fwg - ferrowodginite.

content of F commonly is below detection limit; Ti, $\mathrm{Sn}$ and $\mathrm{U}$ generally decrease along with $\mathrm{Ta} /(\mathrm{Ta}+\mathrm{Nb})$ and reach their lowest contents in $\mathrm{Bi}$-rich pyrochlore. On the other hand, the pyrochlore has the highest $\mathrm{Fe}_{2} \mathrm{O}_{3}$ content, even up to 7.3 wt. \%.

\subsection{Cassiterite}

Cassiterite is an accessory component, associated spatially with tantalite-(Fe) or ferrowodginite (Fig. 2, Fig. 7). It usually forms small grains but a crystal $1 \mathrm{~cm}$ in size was also found. $\mathrm{Ta}_{2} \mathrm{O}_{5}$ exceeds $\mathrm{Nb}_{2} \mathrm{O}_{5}$ in all analyzed crystals, reaching commonly $5.4-5.5$ wt. $\%$ and even 6.4 wt. $\%$ in cassiterite intergrown with ferrowodginite. $\mathrm{Nb}_{2} \mathrm{O}_{5}$ is usually below $1.0 \mathrm{wt} . \%$ (Tab. 4). The cassiterite adjoining tantalite shows a progressive Ta enrichment expressed in increasing $\mathrm{Ta} /(\mathrm{Ta}+\mathrm{Nb})$ from 0.50 to 0.81 , whereas the opposite trend of $\mathrm{Ta} /(\mathrm{Ta}+\mathrm{Nb})$, decreasing from 0.84 to 0.81 , was found in the crystal accompanied by ferrowodginite. In the ternary $(\mathrm{Ti}+\mathrm{Zr}+\mathrm{Sn}+\mathrm{Hf})-(\mathrm{Nb}+\mathrm{Ta}$ $+\mathrm{W})-\left(\mathrm{Fe}_{\mathrm{total}}+\mathrm{Mg}+\mathrm{Mn}+\mathrm{Sc}\right)$ diagram cassiterite compositions plot along the cassiterite - columbite-tantalite tie line (Fig. 5). This suggests the dominant replacement
$\mathrm{R}^{2+}\left(\mathrm{Fe}^{2+}, \mathrm{Mg}^{2+}\right)+2 \mathrm{R}^{5+}\left(\mathrm{Ta}^{5+}, \mathrm{Nb}^{5+}\right) \rightarrow 3 \mathrm{Sn}^{4+}$, typical of cassiterite in many pegmatites worldwide.

\subsection{Ilmenite-group minerals}

Sporadic ilmenite and pyrophanite crystals are usually present as inclusions of micrometer scale (Fig. 7f) and scarcely reach $1 \mathrm{~cm}$. Their chemical compositions (Tab. 5) vary from typical ilmenite with $\mathrm{Mn} /(\mathrm{Mn}+\mathrm{Fe})=0.06$ found in outer parts of the blocky feldspars zone to typical pyrophanite with $\mathrm{Mn} /(\mathrm{Mn}+\mathrm{Fe})=0.82-0.83$ in axial parts of the massive feldspar zone. Both minerals contain only subordinate $\mathrm{Nb}$ and $\mathrm{Ta}\left(\leq 2.57\right.$ wt. $\%$ of $\mathrm{Nb}_{2} \mathrm{O}_{5}$ and 1.02 wt. $\%$ of $\mathrm{Ta}_{2} \mathrm{O}_{5}$ ), always with $\mathrm{Nb}_{2} \mathrm{O}_{5}$ exceeding $\mathrm{Ta}_{2} \mathrm{O}_{5}$. The ilmenite is devoid of $\mathrm{Zn}$, although all other inclusions of the ilmenite-group minerals have $\mathrm{ZnO}$ up to $9.50 \mathrm{wt}$ \%.

\section{Associated ferromagnesian phases}

\subsection{Biotite}

Biotite is a subordinate to accessory constituent and forms: (i) medium- to coarse-grained platy crystals in the 
Tab. 3 Representative compositions of pyrochlore-supergroup minerals

\begin{tabular}{|c|c|c|c|c|c|c|c|c|}
\hline & $\mathrm{P} 13 / \mathrm{a}$ & $\mathrm{P} 13 / \mathrm{b}$ & $109 / \mathrm{a}$ & $109 / \mathrm{b}$ & P119a & P119b & P121a & P120 \\
\hline \multicolumn{9}{|c|}{ wt. \% } \\
\hline $\mathrm{WO}_{3}$ & 0.00 & 0.82 & 0.77 & 1.29 & 0.00 & 0.77 & 0.00 & 0.66 \\
\hline $\mathrm{Nb}_{2} \mathrm{O}_{5}$ & 8.79 & 10.31 & 10.71 & 4.30 & 13.10 & 12.14 & 12.32 & 23.94 \\
\hline $\mathrm{Ta}_{2} \mathrm{O}_{5}$ & 58.72 & 57.79 & 62.76 & 53.67 & 52.82 & 42.79 & 54.82 & 8.38 \\
\hline $\mathrm{SiO}_{2}$ & 0.44 & 0.99 & 0.27 & 1.42 & 0.34 & 1.62 & 0.21 & 2.83 \\
\hline $\mathrm{TiO}_{2}$ & 2.23 & 1.89 & 1.55 & 2.54 & 3.49 & 3.10 & 3.26 & 1.67 \\
\hline $\mathrm{ZrO}_{2}$ & 0.09 & 0.00 & 0.00 & 0.00 & 0.00 & 0.25 & 0.07 & 0.66 \\
\hline $\mathrm{SnO}_{2}$ & 1.58 & 1.54 & 1.56 & 1.30 & 1.62 & 0.86 & 1.79 & 0.11 \\
\hline $\mathrm{ThO}_{2}$ & 0.26 & 0.47 & 0.00 & 0.00 & 0.12 & 0.10 & 0.00 & 0.00 \\
\hline $\mathrm{UO}_{2}$ & 8.88 & 6.54 & 0.00 & 5.05 & 12.10 & 10.58 & 12.18 & 6.80 \\
\hline $\mathrm{Al}_{2} \mathrm{O}_{3}$ & 0.00 & 0.00 & 0.00 & 0.04 & 0.00 & 0.71 & 0.10 & 0.50 \\
\hline $\mathrm{Fe}_{2} \mathrm{O}_{3}$ & 3.09 & 1.13 & 0.00 & 2.10 & 1.23 & 2.35 & 2.51 & 7.33 \\
\hline $\mathrm{Sc}_{2} \mathrm{O}_{3}$ & 0.11 & 0.11 & 0.00 & 0.00 & 0.12 & 0.11 & 0.06 & 0.04 \\
\hline $\mathrm{La}_{2} \mathrm{O}_{3}$ & 0.00 & 0.00 & 0.00 & 0.00 & 0.00 & 0.00 & 0.00 & 0.27 \\
\hline $\mathrm{Ce}_{2} \mathrm{O}_{3}$ & 0.42 & 0.44 & 0.00 & 0.00 & 0.13 & 0.27 & 0.44 & 0.58 \\
\hline $\mathrm{Bi}_{2} \mathrm{O}_{3}$ & 0.00 & 0.00 & 0.00 & 0.00 & 0.00 & 0.00 & 0.00 & 23,96 \\
\hline $\mathrm{MnO}$ & 0.10 & 0.06 & 0.25 & 0.08 & 0.10 & 0.13 & 0.00 & 0.13 \\
\hline $\mathrm{MgO}$ & 0.00 & 0.07 & 0.00 & 0.04 & 0.00 & 0.08 & 0.03 & 0.21 \\
\hline $\mathrm{CaO}$ & 7.86 & 0.82 & 16.62 & 0.65 & 6.52 & 0.70 & 4.30 & 3.82 \\
\hline $\mathrm{BaO}$ & 0.75 & 0.61 & 0.28 & 0.35 & 0.70 & 0.66 & 0.84 & 0.67 \\
\hline $\mathrm{PbO}$ & 0.00 & 10.19 & 0.00 & 20.92 & 0.00 & 13.65 & 0.00 & 9.46 \\
\hline $\mathrm{Na}_{2} \mathrm{O}$ & 0.03 & 0.01 & 0.26 & 0.04 & 0.00 & 0.00 & 0.15 & 0.30 \\
\hline $\mathrm{K}_{2} \mathrm{O}$ & 0.06 & 0.01 & 0.00 & 0.00 & 0.12 & 0.05 & 0.04 & 0.08 \\
\hline $\mathrm{H}_{2} \mathrm{O}^{*}$ & 0.75 & 1.79 & 1.31 & 1.28 & 0.70 & 0.66 & 0.84 & 0.95 \\
\hline $\mathrm{F}$ & 0.00 & 0.00 & 0.80 & 0.00 & 0.00 & 0.00 & 0.00 & 0.00 \\
\hline$-\mathrm{O}=\mathrm{F}_{2}$ & & & -0.34 & & & & & \\
\hline Total & 94.15 & 95.58 & 96.80 & 95.07 & 93.03 & 92.51 & 94.80 & 93.36 \\
\hline \multicolumn{9}{|c|}{ Content of ions based on $\mathrm{B}\left(\mathrm{W}+\mathrm{Nb}+\mathrm{Ta}+\mathrm{Ti}+\mathrm{Zr}+\mathrm{Sn}+\mathrm{Al}+\mathrm{Fe}^{3+}\right)=2 \mathrm{pfu}$} \\
\hline $\mathrm{W}^{6+}$ & 0.000 & 0.018 & 0.017 & 0.032 & 0.000 & 0.018 & 0.000 & 0.016 \\
\hline $\mathrm{Nb}^{5+}$ & 0.323 & 0.397 & 0.405 & 0.186 & 0.484 & 0.483 & 0.434 & 1.031 \\
\hline $\mathrm{Ta}^{5+}$ & 1.297 & 1.339 & 1.429 & 1.395 & 1.173 & 1.024 & 1.161 & 0.217 \\
\hline $\mathrm{Ti}^{4+}$ & 0.136 & 0.121 & 0.097 & 0.183 & 0.215 & 0.205 & 0.191 & 0.120 \\
\hline $\mathrm{Zr}^{4+}$ & 0.003 & 0.000 & 0.000 & 0.000 & 0.000 & 0.011 & 0.003 & 0.031 \\
\hline $\mathrm{Sn}^{4+}$ & 0.051 & 0.052 & 0.052 & 0.050 & 0.053 & 0.030 & 0.056 & 0.004 \\
\hline $\mathrm{Th}^{4+}$ & 0.005 & 0.009 & 0.000 & 0.000 & 0.002 & 0.002 & 0.000 & 0.000 \\
\hline $\mathrm{U}^{4+}$ & 0.161 & 0.124 & 0.000 & 0.107 & 0.220 & 0.207 & 0.211 & 0.144 \\
\hline $\mathrm{Al}^{3+}$ & 0.000 & 0.000 & 0.000 & 0.005 & 0.000 & 0.074 & 0.009 & 0.056 \\
\hline $\mathrm{Fe}^{3+}$ & 0.189 & 0.072 & 0.000 & 0.151 & 0.076 & 0.156 & 0.147 & 0.526 \\
\hline $\mathrm{Sc}^{3+}$ & 0.007 & 0.008 & 0.000 & 0.000 & 0.008 & 0.008 & 0.004 & 0.004 \\
\hline $\mathrm{La}^{3+}$ & 0.000 & 0.000 & 0.000 & 0.000 & 0.000 & 0.000 & 0.000 & 0.010 \\
\hline $\mathrm{Ce}^{3+}$ & 0.012 & 0.014 & 0.000 & 0.000 & 0.004 & 0.009 & 0.013 & 0.020 \\
\hline $\mathrm{Bi}^{3+}$ & 0.000 & 0.000 & 0.000 & 0.000 & 0.000 & 0.000 & 0.000 & 0.588 \\
\hline $\mathrm{Mn}^{2+}$ & 0.007 & 0.004 & 0.018 & 0.006 & 0.007 & 0.010 & 0.000 & 0.010 \\
\hline $\mathrm{Mg}^{2+}$ & 0.000 & 0.009 & 0.000 & 0.006 & 0.000 & 0.010 & 0.003 & 0.030 \\
\hline $\mathrm{Ca}^{2+}$ & 0.684 & 0.075 & 1.490 & 0.066 & 0.571 & 0.066 & 0.359 & 0.390 \\
\hline $\mathrm{Ba}^{2+}$ & 0.024 & 0.020 & 0.009 & 0.013 & 0.022 & 0.023 & 0.026 & 0.025 \\
\hline $\mathrm{Pb}^{2+}$ & 0.000 & 0.234 & 0.000 & 0.538 & 0.000 & 0.323 & 0.000 & 0.243 \\
\hline $\mathrm{Na}^{+}$ & 0.005 & 0.002 & 0.042 & 0.008 & 0.000 & 0.000 & 0.023 & 0.054 \\
\hline $\mathrm{K}^{+}$ & 0.006 & 0.001 & 0.000 & 0.000 & 0.012 & 0.006 & 0.004 & 0.009 \\
\hline $\mathrm{O}^{2-}$ & 5.593 & 4.984 & 6.000 & 5.186 & 5.718 & 5.069 & 5.136 & 6.000 \\
\hline $\mathrm{OH}^{-}$ & 0.407 & 1.016 & 0.733 & 0.814 & 0.282 & 0.931 & 0.864 & 0.601 \\
\hline $\mathrm{F}$ & 0.000 & 0.000 & 0.211 & 0.000 & 0.000 & 0.000 & 0.000 & 0.000 \\
\hline$\Sigma A$ & 0.911 & 0.500 & 1.559 & 0.745 & 0.846 & 0.664 & 0.643 & 1.528 \\
\hline$\Sigma B$ & 2.000 & 2.000 & 2.000 & 2.000 & 2.000 & 2.000 & 2.000 & 2.000 \\
\hline $\mathrm{Mn} /(\mathrm{Mn}+\mathrm{Fe})$ & 0.035 & 0.055 & 1.000 & 0.039 & 0.083 & 0.058 & 0.000 & 0.019 \\
\hline $\mathrm{Ta} /(\mathrm{Ta}+\mathrm{Nb})$ & 0.801 & 0.771 & 0.779 & 0.882 & 0.708 & 0.679 & 0.728 & 0.174 \\
\hline
\end{tabular}

granitic border zone, (ii) elongated lathshaped crystals, up to $60 \mathrm{~cm}$ long, in the wall zone and graphic intermediate zone and (iii) thin giant plates that occur in the inner intermediate zone. Type (iii) is generally observed in the more primitive Julianna pegmatites and gives way to muscovite in the more evolved types. Biotite crystals of this type are often interleaved with muscovite that sometimes forms perfectly shaped pseudohexagonal plates. More random muscovitization of biotite is also common, particularly in the intermediate zones of the pegmatites. Chloritization is widespread. Titanite, ilmenite, rutile, apatite and zircon form common inclusions in biotite. Some of the titanite inclusions are euhedral to subhedral crystals distributed randomly within the biotite host. Others, however, are less regular, subhedral to anhedral, and are grouped along the cleavage planes of biotite. While the first type can represent primary titanite that crystallized simultaneously with biotite, the latter is rather a secondary exsolved titanite. There is no clear relation between the amount of exsolved titanite and the intensity of chloritization, suggesting that the two processes operated independently. The presence of exsolved titanite could indicate partial re-equilibration of biotite with the cooling pegmatiteforming melt. The analyzed biotites, sampled from the border and wall zones from three different pegmatites, are trioctahedral true micas, transitional between ferri- and magnesio-biotites (for the most part annite) and show $\mathrm{Si}$ from 5.46 to $5.65 a p f u$, vi $\mathrm{Al}$ from 0.22 to $0.66 \mathrm{apfu}$ and $\mathrm{Mg}$ from 1.77 to 2.62 apfu. Moderate Ti (0.16-0.46 apfu) and low Mn ( $\leq 0.07$ apfu $), \mathrm{Ca}(\leq 0.02$ $a p f u), \mathrm{Na}(\leq 0.09$ apfu $)$ and $\mathrm{Ba}(\leq 0.02$ $a p f u$ ) were found (Tab. 6, Fig. 8). The biotite compositions from individual veins show slight differences in $\mathrm{Fe} /(\mathrm{Fe}$ $+\mathrm{Mg}$ ) and octahedral Al, which may reflect various degree of fractionation between the pegmatites. Commonly the rims of biotite crystals show lower $\mathrm{Ti}$ and higher octahedral $\mathrm{Al}$ contents compared to the cores. 
Tab. 4 Representative compositions of cassiterite

\begin{tabular}{|c|c|c|c|c|c|c|c|c|}
\hline & P107 & $\mathrm{P} 107 \mathrm{~b}$ & P114a & P114b & P114c & P13a & P13b & $\mathrm{P} 13 \mathrm{c}$ \\
\hline \multicolumn{9}{|c|}{ wt. \% } \\
\hline $\mathrm{WO}_{3}$ & 0.07 & 0.57 & 0.00 & 0.32 & 0.47 & 0.13 & 0.20 & 0.23 \\
\hline $\mathrm{Nb}_{2} \mathrm{O}_{5}$ & 0.77 & 0.78 & 0.83 & 1.10 & 0.92 & 0.58 & 0.77 & 0.93 \\
\hline $\mathrm{Ta}_{2} \mathrm{O}_{5}$ & 1.26 & 5.48 & 1.42 & 3.23 & 5.41 & 5.11 & 5.75 & 6.42 \\
\hline $\mathrm{TiO}_{2}$ & 0.22 & 0.28 & 0.24 & 0.16 & 0.17 & 0.39 & 0.39 & 0.45 \\
\hline $\mathrm{SnO}_{2}$ & 96.33 & 90.89 & 96.47 & 93.55 & 91.14 & 92.87 & 91.57 & 90.00 \\
\hline $\mathrm{Fe}_{2} \mathrm{O}_{3}$ & 0.38 & 0.00 & 0.45 & 0.06 & 0.00 & 0.79 & 0.52 & 1.17 \\
\hline $\mathrm{FeO}$ & 0.13 & 1.07 & 0.06 & 0.80 & 1.04 & 0.54 & 0.85 & 0.72 \\
\hline $\mathrm{MgO}$ & 0.07 & 0.06 & 0.11 & 0.05 & 0.09 & 0.08 & 0.07 & 0.07 \\
\hline Total & 99.24 & 99.13 & 99.57 & 99.27 & 99.24 & 100.48 & 100.13 & 99.98 \\
\hline \multicolumn{9}{|c|}{ Content of ions on the basis of $24 \mathrm{O}$ and 12 cations } \\
\hline $\mathrm{W}^{6+}$ & 0.006 & 0.045 & 0.000 & 0.025 & 0.037 & 0.010 & 0.016 & 0.018 \\
\hline $\mathrm{Nb}^{5+}$ & 0.105 & 0.108 & 0.112 & 0.150 & 0.126 & 0.078 & 0.104 & 0.126 \\
\hline $\mathrm{Ta}^{5+}$ & 0.104 & 0.453 & 0.116 & 0.266 & 0.447 & 0.415 & 0.470 & 0.523 \\
\hline $\mathrm{Ti}^{4+}$ & 0.050 & 0.064 & 0.054 & 0.0376 & 0.038 & 0.087 & 0.089 & 0.100 \\
\hline $\mathrm{Sn}^{4+}$ & 11.583 & 11.017 & 11.553 & 11.282 & 11.036 & 11.064 & 10.960 & 10.758 \\
\hline $\mathrm{Fe}^{3+}$ & 0.087 & 0.000 & 0.102 & 0.014 & 0.000 & 0.177 & 0.118 & 0.264 \\
\hline $\mathrm{Fe}^{2+}$ & 0.034 & 0.271 & 0.014 & 0.202 & 0.265 & 0.134 & 0.214 & 0.181 \\
\hline $\mathrm{Mg}^{2+}$ & 0.033 & 0.028 & 0.049 & 0.024 & 0.042 & 0.034 & 0.030 & 0.030 \\
\hline Ecations & 12.000 & 11.987 & 12.000 & 12.000 & 11.992 & 12.000 & 12.000 & 12.000 \\
\hline $\mathrm{O}^{2-}$ & 24 & 24 & 24 & 24 & 24 & 24 & 24 & 24 \\
\hline$T a /(T a+N b)$ & 0.497 & 0.808 & 0.508 & 0.639 & 0.780 & 0.842 & 0.819 & 0.807 \\
\hline
\end{tabular}

The tourmaline crystals are basically composed of two distinct zones (Fig. 9): (I) a core, showing pleochroism from dark blue / blue / bluish ( $\omega$ ) to colorless $(\varepsilon)$, and (II) a mantle with pleochroism from olive-green / olive-brown / brownish, brown $(\omega)$ to colorless, sometimes with a delicate yellowish tint $(\varepsilon)$. Representative chemical analyses of the two tourmaline generations (I and II), with additional subzones ' $a$ ' and ' $b$ ' in the core and mantle of crystals $\mathrm{T} 1$ and T2 from Fig. 9, are presented in Tab. 7 along with analyses of crystals P2 and P115. In the $\mathrm{X}$-site vacancy-Ca- $(\mathrm{Na}+$ $\mathrm{K})$ classification diagram the analyses plot in the field of the alkali tourmaline group, only occasionally passing into that of the $\mathrm{X}$-vacant tourmaline group

\subsection{Tourmaline}

Black to dark brown tourmaline is the most common accessory mineral associated with the CGM. It occurs as subhedral to euhedral crystals in the graphic intermediate zone up to the quartz core. Trigonal prisms of the tourmaline found in the Julianna- $(4+5)$ dyke reached up to $70 \mathrm{~cm}$ in length and $7 \mathrm{~cm}$ in diameter (Szuszkiewicz et al. in print).

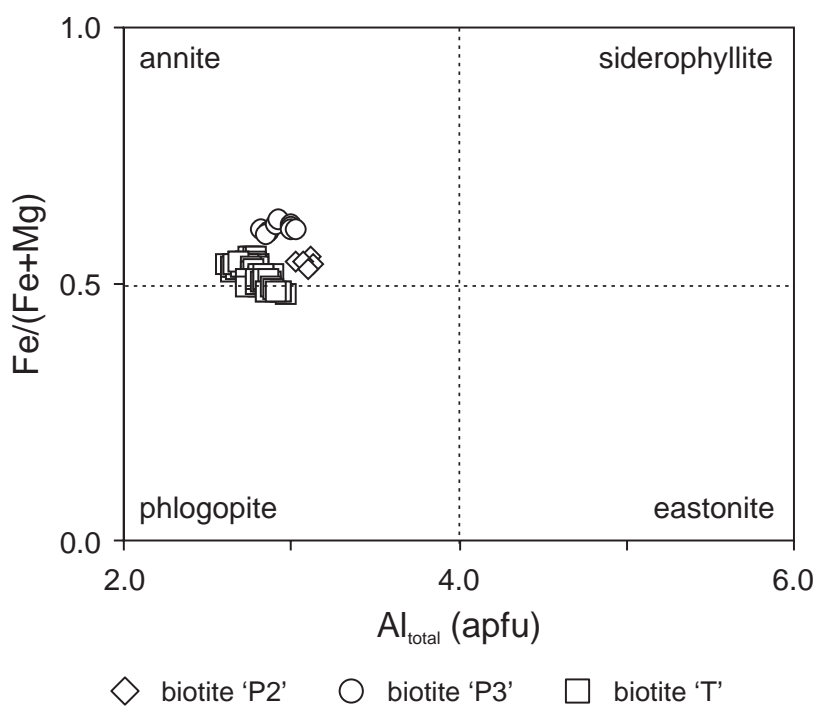

Fig. 8 Compositional plot of biotite in the phlogopite-annite-siderophyllite-eastonite system.
(Fig. 10a). Elevated $\mathrm{Ca}^{2+}$ contents were found only in the P115 tourmaline, adjacent to Ca-bearing minerals like titanite, epidote and zoisite. In the triangle ${ }^{\mathrm{Y}} \mathrm{Fe}(\mathrm{Fe}$ total as $\left.\mathrm{Fe}^{2+}\right)-{ }^{\mathrm{Y}} \mathrm{Al}-{ }^{\mathrm{Y}} \mathrm{Mg}$, all the tourmaline analyses form distinct clusters in different regions of the schorl field (Fig. 10b). Generally, almost all crystals show similar ${ }^{\mathrm{Y}} \mathrm{Al}$ contents. Taking into account relatively abundant vacancy at the $\mathrm{X}$ site, it can reflect the presence of the foitite and magnesiofoitite components. T2 and P115 crystals from internal parts of the pegmatites are distinctly enriched in $\mathrm{Fe}$, whereas crystal $\mathrm{T} 1$, from a thin marginal vein, contains much more $\mathrm{Mg}$. A group of analyses with higher Ca content (P115 tourmaline) plots generally along the line corresponding to the contents $\sim 50$ at. $\%{ }^{\mathrm{Y}} \mathrm{Fe}$, which indicates a dominant $\mathrm{Mg} \rightarrow \mathrm{Al}$ replacement. The positive covariations ${ }^{\mathrm{X}} \mathrm{Ca}$ vs. ${ }^{\mathrm{Y}} \mathrm{Mg}$ or ${ }^{\mathrm{Y}}(\mathrm{Mg}+\mathrm{Fe})$ and negative ${ }^{\mathrm{X}} \mathrm{Ca}$ vs. ${ }^{\mathrm{Y}} \mathrm{Al}$ (each with a coefficient $\sim 2.0$ ) and ${ }^{\mathrm{x}} \mathrm{Ca}$ vs. X-site vacancy $(\sim 1.0)$ (Fig. 11) prove a significant role for the substitution ${ }^{\mathrm{x}} \mathrm{Ca}+2^{\mathrm{Y}} \mathrm{Mg}^{2+} \rightarrow{ }^{\mathrm{x}} \square+2^{\mathrm{Y}} \mathrm{Al}^{3+}$, with a small amount of ${ }^{\mathrm{Y}} \mathrm{Al}^{3+}$ replaced by $\mathrm{Ti}^{4+}$.

Titanium is the only component that seems to correlate with the observed differences in tourmaline pleochroism. The bluish core (Ia in Tab. 7 and Fig. 9) has very low $\mathrm{Ti}^{4+}$ contents, from less than 0.005 to $\sim 0.020$ $a p f u$, and low $\mathrm{Mn} /(\mathrm{Mn}+\mathrm{Fe})$ ranging from c. 0.005 to slightly above 0.030 (Fig. 12). The outermost zone of

Fig. 9 Internal texture of tourmaline crystals in transverse sections: $\mathbf{a}$ - crystal T2 from an internal part of the Julianna dyke; $\mathbf{b}$ - crystals T1 from a peripheral pegmatite vein. 
Tab. 5 Representative compositions of ilmenite-group minerals

\begin{tabular}{|c|c|c|c|c|c|c|c|c|}
\hline & $\begin{array}{c}\text { ES4a } \\
\text { Ilm }\end{array}$ & $\begin{array}{c}\text { P120a } \\
\text { Ilm }\end{array}$ & $\begin{array}{c}\text { P120b } \\
\text { Ilm }\end{array}$ & $\begin{array}{c}\text { P120c } \\
\text { Ilm }\end{array}$ & $\begin{array}{c}\text { P120d } \\
\text { Ilm }\end{array}$ & $\begin{array}{c}\text { P120e } \\
\text { Ilm }\end{array}$ & $\begin{array}{c}\text { P120f } \\
\text { Prf }\end{array}$ & $\begin{array}{c}\text { P133 } \\
\text { Prf }\end{array}$ \\
\hline \multicolumn{9}{|c|}{ wt. \% } \\
\hline $\mathrm{WO}_{3}$ & 0.00 & 0.00 & 0.00 & 0.00 & 0.00 & 0.00 & 0.00 & 0.38 \\
\hline $\mathrm{Nb}_{2} \mathrm{O}_{5}$ & 0.61 & 1.25 & 2.27 & 2.57 & 1.30 & 0.61 & 0.85 & 0.43 \\
\hline $\mathrm{Ta}_{2} \mathrm{O}_{5}$ & 0.30 & 0.30 & 1.02 & 0.75 & 0.16 & 0.18 & 0.18 & 0.00 \\
\hline $\mathrm{TiO}_{2}$ & 51.23 & 51.24 & 49.31 & 51.20 & 52.32 & 51.30 & 50.65 & 51.48 \\
\hline $\mathrm{Al}_{2} \mathrm{O}_{3}$ & 0.00 & 0.00 & 0.23 & 0.00 & 0.00 & 0.04 & 0.18 & 0.00 \\
\hline $\mathrm{Sc}_{2} \mathrm{O}_{3}$ & 0.03 & 0.00 & 0.00 & 0.00 & 0.00 & 0.00 & 0.00 & 0.00 \\
\hline $\mathrm{V}_{2} \mathrm{O}_{3}$ & 0.00 & 0.00 & 0.00 & 0.18 & 0.19 & 0.23 & 0.00 & 0.17 \\
\hline $\mathrm{Fe}_{2} \mathrm{O}_{3}$ & 0.58 & 0.00 & 0.00 & 0.00 & 0.00 & 0.00 & 0.00 & 0.05 \\
\hline $\mathrm{Ce}_{2} \mathrm{O}_{3}$ & 0.13 & 0.14 & 0.14 & 0.00 & 0.00 & 0.14 & 0.00 & 0.00 \\
\hline $\mathrm{FeO}$ & 43.89 & 27.58 & 26.85 & 22.77 & 22.18 & 22.67 & 16.38 & 8.06 \\
\hline $\mathrm{MnO}$ & 2.81 & 16.76 & 15.12 & 15.88 & 16.34 & 16.01 & 19.64 & 37.67 \\
\hline $\mathrm{MgO}$ & 0.12 & 0.00 & 0.00 & 0.00 & 0.00 & 0.00 & 0.00 & 0.00 \\
\hline $\mathrm{CaO}$ & 0.00 & 0.00 & 0.30 & 0.15 & 0.14 & 0.23 & 0.00 & 0.00 \\
\hline $\mathrm{ZnO}$ & 0.00 & 0.83 & 2.51 & 5.41 & 7.09 & 8.21 & 9.50 & 1.04 \\
\hline Total & 99.69 & 98.09 & 97.77 & 98.93 & 99.72 & 99.62 & 97.38 & 99.27 \\
\hline \multicolumn{9}{|c|}{ Content of ions on the basis of $3 \mathrm{O}$ pfu } \\
\hline $\mathrm{W}^{6+}$ & 0.000 & 0.000 & 0.000 & 0.000 & 0.000 & 0.000 & 0.000 & 0.003 \\
\hline $\mathrm{Nb}^{5+}$ & 0.007 & 0.015 & 0.027 & 0.030 & 0.015 & 0.007 & 0.010 & 0.005 \\
\hline $\mathrm{Ta}^{5+}$ & 0.002 & 0.002 & 0.007 & 0.005 & 0.001 & 0.001 & 0.001 & 0.000 \\
\hline $\mathrm{Ti}^{4+}$ & 0.980 & 0.991 & 0.965 & 0.985 & 0.998 & 0.998 & 0.994 & 0.985 \\
\hline $\mathrm{Al}^{3+}$ & 0.000 & 0.000 & 0.007 & 0.000 & 0.000 & 0.001 & 0.006 & 0.000 \\
\hline $\mathrm{Sc}^{3+}$ & 0.001 & 0.000 & 0.000 & 0.000 & 0.000 & 0.000 & 0.000 & 0.000 \\
\hline $\mathrm{V}^{3+}$ & 0.000 & 0.000 & 0.000 & 0.004 & 0.004 & 0.005 & 0.000 & 0.003 \\
\hline $\mathrm{Fe}^{3+}$ & 0.011 & 0.000 & 0.000 & 0.000 & 0.000 & 0.000 & 0.000 & 0.001 \\
\hline $\mathrm{Ce}^{3+}$ & 0.001 & 0.001 & 0.001 & 0.000 & 0.000 & 0.001 & 0.000 & 0.000 \\
\hline $\mathrm{Fe}^{2+}$ & 0.933 & 0.593 & 0.584 & 0.487 & 0.470 & 0.485 & 0.358 & 0.171 \\
\hline $\mathrm{Mn}^{2+}$ & 0.060 & 0.365 & 0.333 & 0.344 & 0.351 & 0.347 & 0.434 & 0.812 \\
\hline $\mathrm{Mg}^{2+}$ & 0.005 & 0.000 & 0.000 & 0.000 & 0.000 & 0.000 & 0.000 & 0.000 \\
\hline $\mathrm{Ca}^{2+}$ & 0.000 & 0.000 & 0.008 & 0.004 & 0.004 & 0.006 & 0.000 & 0.000 \\
\hline $\mathrm{Zn}^{2+}$ & 0.000 & 0.016 & 0.048 & 0.102 & 0.133 & 0.155 & 0.183 & 0.020 \\
\hline$\Sigma$ cations & 2.000 & 1.983 & 1.980 & 1.961 & 1.976 & 1.996 & 1.986 & 2.000 \\
\hline $\mathrm{O}^{2-}$ & 3 & 3 & 3 & 3 & 3 & 3 & 3 & 3 \\
\hline$M n /(M n+F e)$ & 0.060 & 0.381 & 0.363 & 0.414 & 0.427 & 0.417 & 0.548 & 0.825 \\
\hline$T a /(T a+N b)$ & 0.229 & 0.126 & 0.213 & 0.150 & 0.070 & 0.149 & 0.114 & 0.000 \\
\hline
\end{tabular}

Note: $\mathrm{Zr}, \mathrm{Sn}$ and REE (except for $\mathrm{Ce}$ ) are below detection. Abbreviations: Ilm - ilmenite, Prf - pyrophanite the core, with blue-olive pleochroism constitutes a transitional subzone with slightly higher $\mathrm{Ti}$, up to 0.040 apfu (Ib in Tab. 7 and Fig. 9). The internal olive-brown part of the mantle has Ti from 0.040 to slightly above $0.090 \mathrm{apfu}$ at generally decreasing $\mathrm{Mn} /(\mathrm{Mn}$ $+\mathrm{Fe}$ ) from 0.030 to about 0.010 . In the outermost zones of some brown tourmaline crystals, the $\mathrm{Ti}$ content reaches $0.12-0.15$ apfu with $\mathrm{Mn} /(\mathrm{Mn}+\mathrm{Fe})$ decreasing as before down to 0.005 . The $\mathrm{Fe} / \mathrm{Ti}$ ratio ranges from $120-60$ in the blue core, through 30-20 in olive, olive-brownish and brownish mantle, to 15-10 in the outermost, brown zone of some Mg-enriched crystals. In accordance with the spectroscopic data of Mattson and Rossman (1987) and da FonsecaZang et al. (2008), these data suggest that the internal texture of the tourmaline crystals results mainly from the spin-allowed crystal field transitions of $\mathrm{Fe}^{2+}$ and the $\mathrm{Fe}^{2+}-\mathrm{Fe}^{3+}$ charge-transfer transitions responsible for blue color of the core and the $\mathrm{Fe}^{2+}-\mathrm{Ti}^{4+}$ charge-transfer transitions responsible for the yellowish-brown to brown color of the mantle. Tourmaline, as in CGM and other $\mathrm{Nb}-$ Ta oxides, reflects the reversed $\mathrm{Mn}-\mathrm{Fe}$ fractionation trend in the transition from the stage of early

a

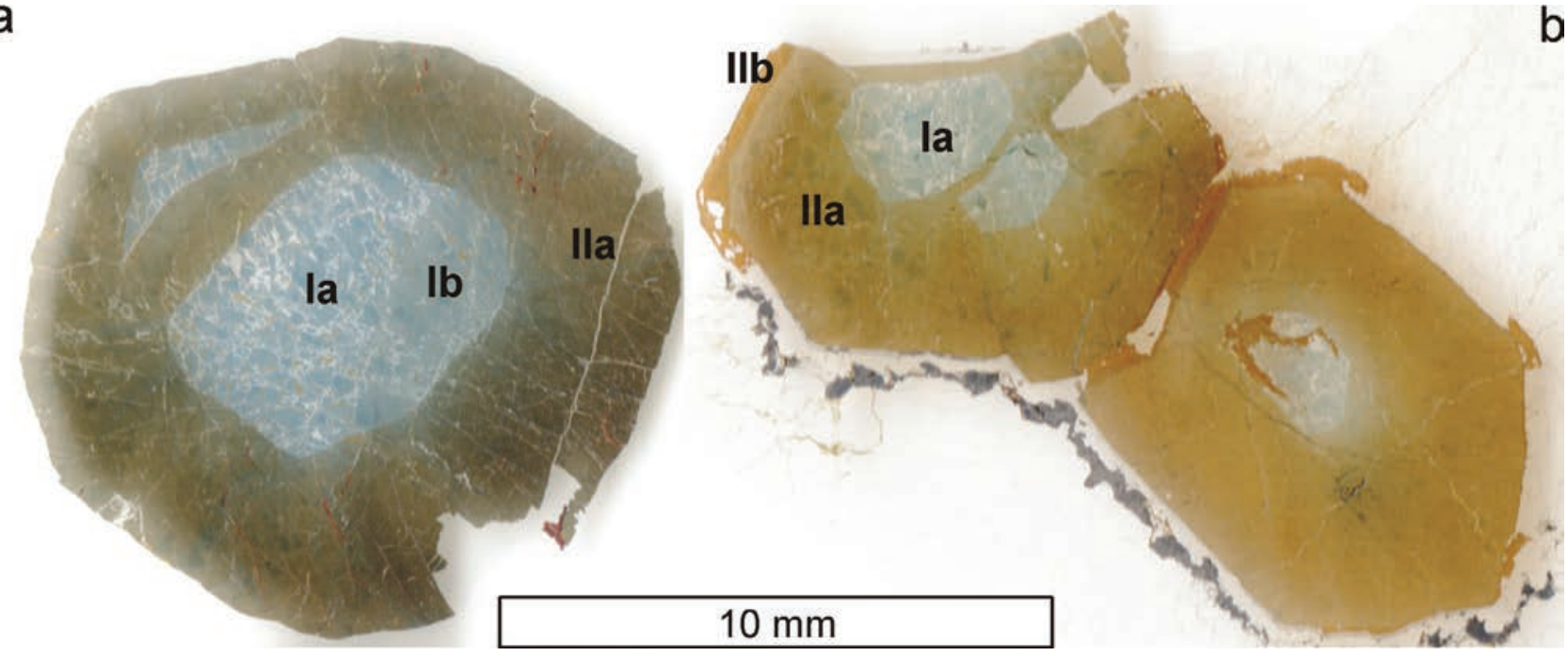


Tab. 6. Representative compositions of biotite

\begin{tabular}{|c|c|c|c|c|c|c|c|c|}
\hline & $\begin{array}{c}\mathrm{P} 2 / 1 \mathrm{~A} \# 5 \\
\text { core }\end{array}$ & $\begin{array}{c}\mathrm{P} 2 / 1 \mathrm{~A} \# 4 \\
\operatorname{rim}\end{array}$ & $\begin{array}{c}\text { P3/2A\#1 } \\
\text { core }\end{array}$ & $\begin{array}{c}\mathrm{P} 3 / 2 \mathrm{~A} \# 2 \\
\rightarrow\end{array}$ & $\begin{array}{c}\mathrm{P} 3 / 2 \mathrm{~A} \# 3 \\
\text { rim }\end{array}$ & $\begin{array}{c}\mathrm{T} / 1 \mathrm{~A} \# 35 \\
\text { core }\end{array}$ & $\begin{array}{c}\mathrm{T} / 1 \mathrm{A \# 37} \\
\rightarrow\end{array}$ & $\begin{array}{c}\mathrm{T} / 1 \mathrm{A \# 38} \\
\mathrm{rim}\end{array}$ \\
\hline \multicolumn{9}{|c|}{ wt. \% } \\
\hline $\mathrm{SiO}_{2}$ & 36.06 & 36.04 & 35.39 & 35.47 & 35.14 & 36.36 & 36.22 & 36.35 \\
\hline $\mathrm{TiO}_{2}$ & 2.33 & 1.59 & 3.85 & 3.62 & 3.17 & 3.66 & 3.16 & 2.66 \\
\hline $\mathrm{Al}_{2} \mathrm{O}_{3}$ & 17.12 & 16.95 & 15.91 & 15.96 & 16.34 & 14.99 & 15.44 & 15.94 \\
\hline $\mathrm{FeO}_{\text {tot }}$ & 19.58 & 20.73 & 22.90 & 23.01 & 23.01 & 20.70 & 21.17 & 20.05 \\
\hline $\mathrm{MnO}$ & 0.00 & 0.00 & 0.34 & 0.50 & 0.46 & 0.00 & 0.00 & 0.00 \\
\hline $\mathrm{MgO}$ & 9.67 & 9.77 & 7.89 & 7.65 & 7.83 & 9.62 & 10.00 & 10.34 \\
\hline $\mathrm{CaO}$ & 0.14 & 0.00 & 0.00 & 0.00 & 0.00 & 0.00 & 0.00 & 0.00 \\
\hline $\mathrm{Na}_{2} \mathrm{O}$ & 0.00 & 0.09 & 0.12 & 0.10 & 0.13 & 0.23 & 0.14 & 0.18 \\
\hline $\mathrm{K}_{2} \mathrm{O}$ & 10.03 & 9.89 & 9.44 & 9.42 & 9.55 & 9.31 & 9.07 & 9.19 \\
\hline $\mathrm{BaO}$ & 0.00 & 0.00 & 0.12 & 0.02 & 0.00 & 0.00 & 0.00 & 0.32 \\
\hline $\mathrm{H}_{2} \mathrm{O}^{*}$ & 3.90 & 3.89 & 3.87 & 3.86 & 3.86 & 3.89 & 3.90 & 3.90 \\
\hline Total & 98.83 & 98.95 & 99.83 & 99.61 & 99.48 & 98.76 & 99.09 & 98.93 \\
\hline \multicolumn{9}{|c|}{ Contents of ions on the basis of $22 \mathrm{O}$ apfu } \\
\hline $\mathrm{Si}$ & 5.539 & 5.555 & 5.480 & 5.504 & 5.464 & 5.611 & 5.572 & 5.583 \\
\hline $\mathrm{Al}^{\mathrm{IV}}$ & 2.461 & 2.445 & 2.520 & 2.496 & 2.536 & 2.389 & 2.428 & 2.417 \\
\hline$\Sigma Z$ & 8.000 & 8.000 & 8.000 & 8.000 & 8.000 & 8.000 & 8.000 & 8.000 \\
\hline $\mathrm{Al}^{\mathrm{VI}}$ & 0.638 & 0.634 & 0.383 & 0.423 & 0.460 & 0.339 & 0.372 & 0.470 \\
\hline $\mathrm{Ti}$ & 0.269 & 0.184 & 0.448 & 0.423 & 0.371 & 0.425 & 0.365 & 0.307 \\
\hline $\mathrm{Fe}^{2+}$ & 2.515 & 2.672 & 2.966 & 2.985 & 2.992 & 2.672 & 2.723 & 2.576 \\
\hline Mn & 0.000 & 0.000 & 0.044 & 0.065 & 0.061 & 0.000 & 0.000 & 0.000 \\
\hline Mg & 2.214 & 2.245 & 1.822 & 1.768 & 1.816 & 2.214 & 2.292 & 2.367 \\
\hline$\Sigma Y$ & 5.637 & 5.736 & 5.663 & 5.664 & 5.700 & 5.649 & 5.752 & 5.720 \\
\hline $\mathrm{Ca}$ & 0.023 & 0.000 & 0.000 & 0.000 & 0.000 & 0.000 & 0.000 & 0.000 \\
\hline $\mathrm{Na}$ & 0.000 & 0.027 & 0.036 & 0.031 & 0.040 & 0.069 & 0.042 & 0.054 \\
\hline K & 1.965 & 1.944 & 1.864 & 1.865 & 1.893 & 1.832 & 1.779 & 1.801 \\
\hline $\mathrm{Ba}$ & 0.000 & 0.000 & 0.007 & 0.001 & 0.000 & 0.000 & 0.000 & 0.019 \\
\hline$\Sigma X$ & 1.988 & 1.971 & 1.908 & 1.897 & 1.934 & 1.902 & 1.821 & 1.874 \\
\hline $\mathrm{Fe} /(\mathrm{Fe}+\mathrm{Mg})$ & 0.543 & 0.532 & 0.619 & 0.628 & 0.622 & 0.547 & 0.543 & 0.521 \\
\hline
\end{tabular}

Note: $\mathrm{Rb}, \mathrm{Cs}, \mathrm{Sn}, \mathrm{P}$ and $\mathrm{F}$ are below detection limits. All Fe as $\mathrm{Fe}^{2+}, \mathrm{H}_{2} \mathrm{O}$ based on stoichiometry. crystallization from Ti-poor melt to the later stage with increasing role of Fe and $\mathrm{Ti}$ (and especially $\mathrm{Ti}$ relative $\mathrm{Fe}$ ), and Mn decreasing.

\subsection{Garnet}

The almandine-spessartine variety of garnet is common in the blocky feldspar zone and the quartz core, where it forms well-developed crystals up to $5 \mathrm{~cm}$ across. Oval aggregates of skeletal garnet intergrown with quartz and, more rarely, with microcline and muscovite, up to $10 \mathrm{~cm}$ in diameter, were observed in the graphic zone (Szuszkiewicz et al. in print). The primary garnet has negligible $\mathrm{Ca}$ and $\mathrm{Mg}$ contents and displays a moderate degree of $\mathrm{Mn}-\mathrm{Fe}$ fractionation with $\mathrm{Mn} /(\mathrm{Mn}+\mathrm{Fe})$ from $\sim 0.40$ to slightly above 0.50 (Tab. 8). It corresponds closely to a degree of $\mathrm{Mn}-\mathrm{Fe}$ fractionation displayed by crystals of the CGM that occur in the immediate

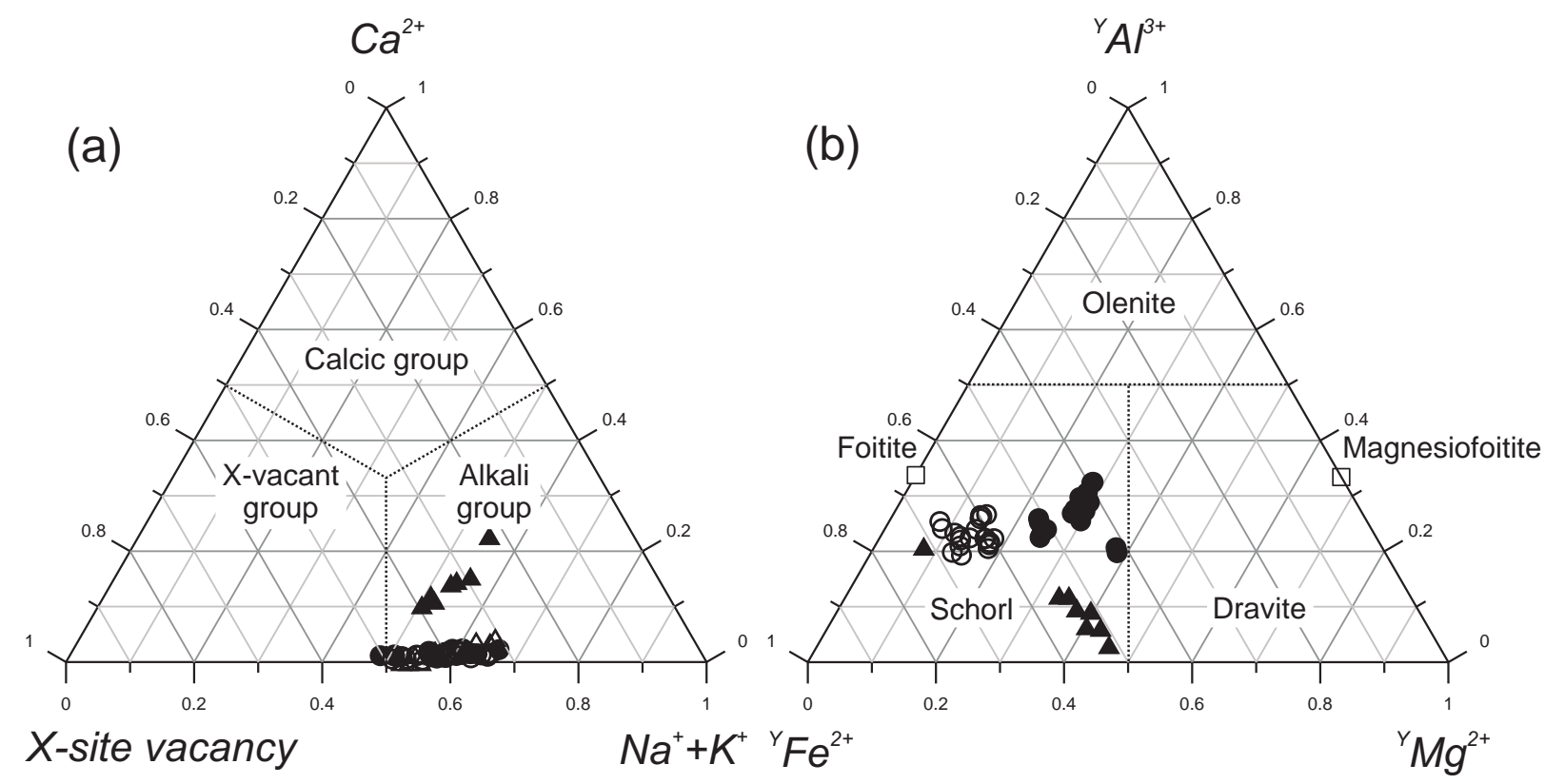

$\begin{array}{lll}\bigcirc & \text { tourmaline T1 } & \triangle \text { tourmaline P4 } \\ \text { tourmaline T2 } & \Delta \text { tourmaline P115 }\end{array}$ 
(Fe,Mn)-(Ti,Sn)-(Nb, Ta) oxide assemblage in the mixed pegmatite from the Sowie Mts block, Poland

Tab. 7 Representative compositions of tourmaline

\begin{tabular}{|c|c|c|c|c|c|c|c|c|c|c|c|c|c|}
\hline & $\begin{array}{c}\text { T1a/11 } \\
\text { Ia }\end{array}$ & $\begin{array}{c}\mathrm{T} 1 \mathrm{~b} / 20 \\
\text { Ia }\end{array}$ & $\begin{array}{c}\mathrm{T} 2 \mathrm{a} / 4 \\
\text { Ia }\end{array}$ & $\begin{array}{c}\mathrm{T} 2 \mathrm{~b} / 10 \\
\text { Ia }\end{array}$ & $\begin{array}{c}\mathrm{T} 2 \mathrm{a} / 3 \\
\mathrm{Ib}\end{array}$ & $\begin{array}{c}\text { T1a/12 } \\
\text { IIa }\end{array}$ & $\begin{array}{c}\text { T1a/3 } \\
\text { IIa }\end{array}$ & $\begin{array}{c}\mathrm{T} 2 \mathrm{a} / 7 \\
\text { IIa }\end{array}$ & $\begin{array}{c}\text { T2a/8 } \\
\text { IIa }\end{array}$ & $\begin{array}{c}\mathrm{T} 2 \mathrm{~b} / 12 \\
\text { IIa }\end{array}$ & $\begin{array}{c}\mathrm{T} 2 \mathrm{~b} / 9 \\
\text { IIa }\end{array}$ & $\begin{array}{c}\mathrm{T} 1 \mathrm{a} / 2 \\
\mathrm{IIb}\end{array}$ & $\begin{array}{c}\text { T1a/4 } \\
\text { IIb }\end{array}$ \\
\hline \multicolumn{14}{|c|}{ wt. \% } \\
\hline $\mathrm{SiO}_{2}$ & 36.44 & 36.38 & 35.68 & 35.52 & 35.58 & 36.04 & 35.85 & 35.50 & 35.24 & 34.83 & 35.00 & 35.50 & 36.19 \\
\hline $\mathrm{TiO}_{2}$ & 0.16 & 0.14 & 0.12 & 0.12 & 0.24 & 0.47 & 0.55 & 0.49 & 0.66 & 0.53 & 0.64 & 0.79 & 0.96 \\
\hline $\mathrm{B}_{2} \mathrm{O}_{3}$ & 10.61 & 10.61 & 10.39 & 10.38 & 10.35 & 10.57 & 10.57 & 10.33 & 10.32 & 10.28 & 10.27 & 10.45 & 10.57 \\
\hline $\mathrm{Al}_{2} \mathrm{O}_{3}$ & 36.23 & 35.83 & 34.49 & 34.61 & 34.27 & 35.65 & 35.35 & 33.73 & 33.77 & 34.06 & 34.13 & 34.61 & 34.25 \\
\hline $\mathrm{FeO}$ & 8.48 & 9.25 & 12.55 & 12.29 & 12.57 & 8.82 & 9.47 & 13.36 & 13.36 & 13.32 & 13.50 & 10.54 & 8.69 \\
\hline $\mathrm{MnO}$ & 0.15 & 0.09 & 0.29 & 0.41 & 0.25 & 0.19 & 0.12 & 0.30 & 0.19 & 0.38 & 0.38 & 0.11 & 0.03 \\
\hline $\mathrm{MgO}$ & 3.43 & 3.36 & 1.66 & 1.71 & 1.63 & 3.51 & 3.55 & 1.44 & 1.48 & 1.29 & 0.90 & 2.95 & 4.33 \\
\hline $\mathrm{CaO}$ & 0.06 & 0.07 & 0.03 & 0.03 & 0.07 & 0.09 & 0.14 & 0.07 & 0.09 & 0.11 & 0.05 & 0.04 & 0.12 \\
\hline $\mathrm{Na}_{2} \mathrm{O}$ & 1.60 & 1.52 & 1.52 & 1.61 & 1.64 & 1.83 & 1.88 & 1.85 & 1.89 & 1.82 & 1.77 & 1.78 & 1.88 \\
\hline $\mathrm{K}_{2} \mathrm{O}$ & 0.00 & 0.00 & 0.07 & 0.02 & 0.03 & 0.04 & 0.03 & 0.01 & 0.03 & 0.02 & 0.04 & 0.00 & 0.05 \\
\hline $\mathrm{H}_{2} \mathrm{O}$ & 3.21 & 3.31 & 3.32 & 3.32 & 3.25 & 3.18 & 3.26 & 3.23 & 3.21 & 3.25 & 3.18 & 3.26 & 3.25 \\
\hline Total & 100.37 & 100.59 & 100.11 & 100.01 & 99.88 & 100.39 & 100.77 & 100.28 & 100.24 & 99.90 & 99.84 & 100.03 & 100.42 \\
\hline \multicolumn{14}{|c|}{ Content of ions on the basis of $31(\mathrm{O}, \mathrm{OH})$ and $15(\mathrm{Y}, \mathrm{Z}, \mathrm{T})$ apfu } \\
\hline $\mathrm{Na}^{+}$ & 0.508 & 0.484 & 0.492 & 0.523 & 0.534 & 0.583 & 0.601 & 0.602 & 0.619 & 0.596 & 0.579 & 0.575 & 0.600 \\
\hline $\mathrm{K}^{+}$ & 0.000 & 0.000 & 0.015 & 0.005 & 0.007 & 0.008 & 0.006 & 0.001 & 0.007 & 0.004 & 0.009 & 0.000 & 0.010 \\
\hline $\mathrm{Ca}^{2+}$ & 0.011 & 0.011 & 0.005 & 0.005 & 0.012 & 0.016 & 0.024 & 0.012 & 0.016 & 0.020 & 0.008 & 0.007 & 0.022 \\
\hline vacancy & 0.481 & 0.505 & 0.488 & 0.467 & 0.447 & 0.393 & 0.369 & 0.385 & 0.358 & 0.380 & 0.404 & 0.418 & 0.368 \\
\hline$\Sigma X$ & 1.000 & 1.000 & 1.000 & 1.000 & 1.000 & 1.000 & 1.000 & 1.000 & 1.000 & 1.000 & 1.000 & 1.000 & 1.000 \\
\hline${ }^{\mathrm{Y}} \mathrm{Al}^{3+}$ & 0.901 & 0.882 & 0.774 & 0.779 & 0.759 & 0.841 & 0.743 & 0.657 & 0.636 & 0.670 & 0.727 & 0.691 & 0.524 \\
\hline${ }^{\mathrm{Y}} \mathrm{Mn}^{2+}$ & 0.021 & 0.013 & 0.041 & 0.058 & 0.035 & 0.026 & 0.017 & 0.042 & 0.028 & 0.055 & 0.054 & 0.015 & 0.005 \\
\hline${ }^{\mathrm{Y}} \mathrm{Fe}^{2+}$ & 1.161 & 1.267 & 1.757 & 1.721 & 1.765 & 1.214 & 1.302 & 1.879 & 1.881 & 1.882 & 1.911 & 1.466 & 1.196 \\
\hline${ }^{\mathrm{Y}} \mathrm{Mg}^{2+}$ & 0.837 & 0.820 & 0.413 & 0.427 & 0.409 & 0.861 & 0.870 & 0.361 & 0.371 & 0.325 & 0.227 & 0.730 & 1.087 \\
\hline${ }^{\mathrm{Y}} \mathrm{Ti}^{4+}$ & 0.020 & 0.018 & 0.015 & 0.015 & 0.031 & 0.058 & 0.068 & 0.061 & 0.084 & 0.068 & 0.081 & 0.098 & 0.118 \\
\hline$\Sigma Y$ & 3.000 & 3.000 & 3.000 & 3.000 & 3.000 & 3.000 & 3.000 & 3.000 & 3.000 & 3.000 & 3.000 & 3.000 & 3.000 \\
\hline${ }^{\mathrm{z}} \mathrm{Al}^{3+}$ & 6.000 & 6.000 & 6.000 & 6.000 & 6.000 & 6.000 & 6.000 & 6.000 & 6.000 & 6.000 & 6.000 & 6.000 & 6.000 \\
\hline $\mathrm{B}^{3+}$ & 3.000 & 3.000 & 3.000 & 3.000 & 3.000 & 3.000 & 3.000 & 3.000 & 3.000 & 3.000 & 3.000 & 3.000 & 3.000 \\
\hline${ }^{\mathrm{T}} \mathrm{Si}^{4+}$ & 5.968 & 5.960 & 5.971 & 5.948 & 5.976 & 5.928 & 5.894 & 5.971 & 5.934 & 5.887 & 5.922 & 5.905 & 5.954 \\
\hline${ }^{\mathrm{T}} \mathrm{Al}^{3+}$ & 0.032 & 0.040 & 0.029 & 0.052 & 0.024 & 0.072 & 0.106 & 0.029 & 0.066 & 0.113 & 0.078 & 0.095 & 0.046 \\
\hline$\Sigma T$ & 6.000 & 6.000 & 6.000 & 6.000 & 6.000 & 6.000 & 6.000 & 6.000 & 6.000 & 6.000 & 6.000 & 6.000 & 6.000 \\
\hline $\mathrm{O}^{2-}$ & 27.497 & 27.384 & 27.292 & 27.296 & 27.363 & 27.509 & 27.428 & 27.378 & 27.396 & 27.331 & 27.416 & 27.382 & 27.438 \\
\hline $\mathrm{OH}^{-}$ & 3.503 & 3.616 & 3.708 & 3.704 & 3.637 & 3.491 & 3.572 & 3.622 & 3.604 & 3.669 & 3.584 & 3.618 & 3.562 \\
\hline$M n /(M n+F e)$ & 0.018 & 0.010 & 0.015 & 0.015 & 0.031 & 0.021 & 0.013 & 0.022 & 0.014 & 0.028 & 0.027 & 0.010 & 0.004 \\
\hline
\end{tabular}

neighborhood of, or form inclusions in, the garnet. Some crystals show an 'island' texture with numerous relics of the primary almandine-spessartine garnet cross-cut by a younger Ca-enriched spessartine (Fig. 13). The younger generation of garnet displays somewhat higher $\mathrm{Mn} /(\mathrm{Mn}$ $+\mathrm{Fe}$ ) values of $0.60-0.63$. The internal texture of such crystals and the distinct decrease in $\mathrm{Fe}^{2+}$ in the secondary garnet suggest metasomatic replacement of $\mathrm{Fe}^{2+}$ by $\mathrm{Ca}^{2+}$ along a net of random fractures in the primary garnet crystals.

\section{Concluding remarks}

The $\mathrm{Fe}^{2+}-\mathrm{Mn}^{2+}$ balance in the melt changed due to the appearance of additional $\mathrm{Fe}, \mathrm{Ti}, \mathrm{Mg}$ and $\mathrm{Ca}$ and the

Fig. 10 Ternary plots of tourmaline compositions from the Julianna-type dykes: $\mathbf{a}-\mathrm{X}$-site vacancy-Ca ${ }^{2+}-(\mathrm{Na}+\mathrm{K})^{+} ; \mathbf{b}-{ }^{\mathrm{Y}} \mathrm{Fe}-{ }^{\mathrm{Y}} \mathrm{Al}-{ }^{\mathrm{Y}} \mathrm{Mg}$. preferred incorporation of $\mathrm{Fe}^{2+}$ over $\mathrm{Mn}^{2+}$ by the CGM. Increasing abundances of $\mathrm{Ti}^{4+}, \mathrm{Sn}^{4+}, \mathrm{Fe}^{3+}$ and $\mathrm{Sc}^{3+}$ during late stages of columbite-(Fe) - columbite-( $\mathrm{Mn})$ crystallization resulted also from the euxenite-type substitution $\mathrm{R}^{2+}+\mathrm{R}^{5+} \leftrightarrow \mathrm{R}^{3+}+\mathrm{R}^{4+}$. This mechanism led finally to the crystallization of ixiolite and ferrowodginite. A progressive increase in $\mathrm{Ti}^{4+}$ content of the melt is marked by the composition of tourmaline associated with the CGM, whereas the increasing activity of $\mathrm{Mg}$ and/or $\mathrm{Ca}$ is reflected by Ca-enriched schorl evolving to dravite, metasomatic alteration of primary almandine-spessartine garnet to Ca-bearing spessartine, alterations of primary CGM and by crystallization of secondary Ca-rich members of the pyrochlore, microlite and betafite groups at the expense of columbite-, samarskite- and euxenite-group minerals.

The anomalies in $\mathrm{Mn}-\mathrm{Fe}$ and $\mathrm{Ta}-\mathrm{Nb}$ fractionation in Nb-Ta minerals can be explained by (1) in situ contamination of the pegmatite-forming melt by the sur- 

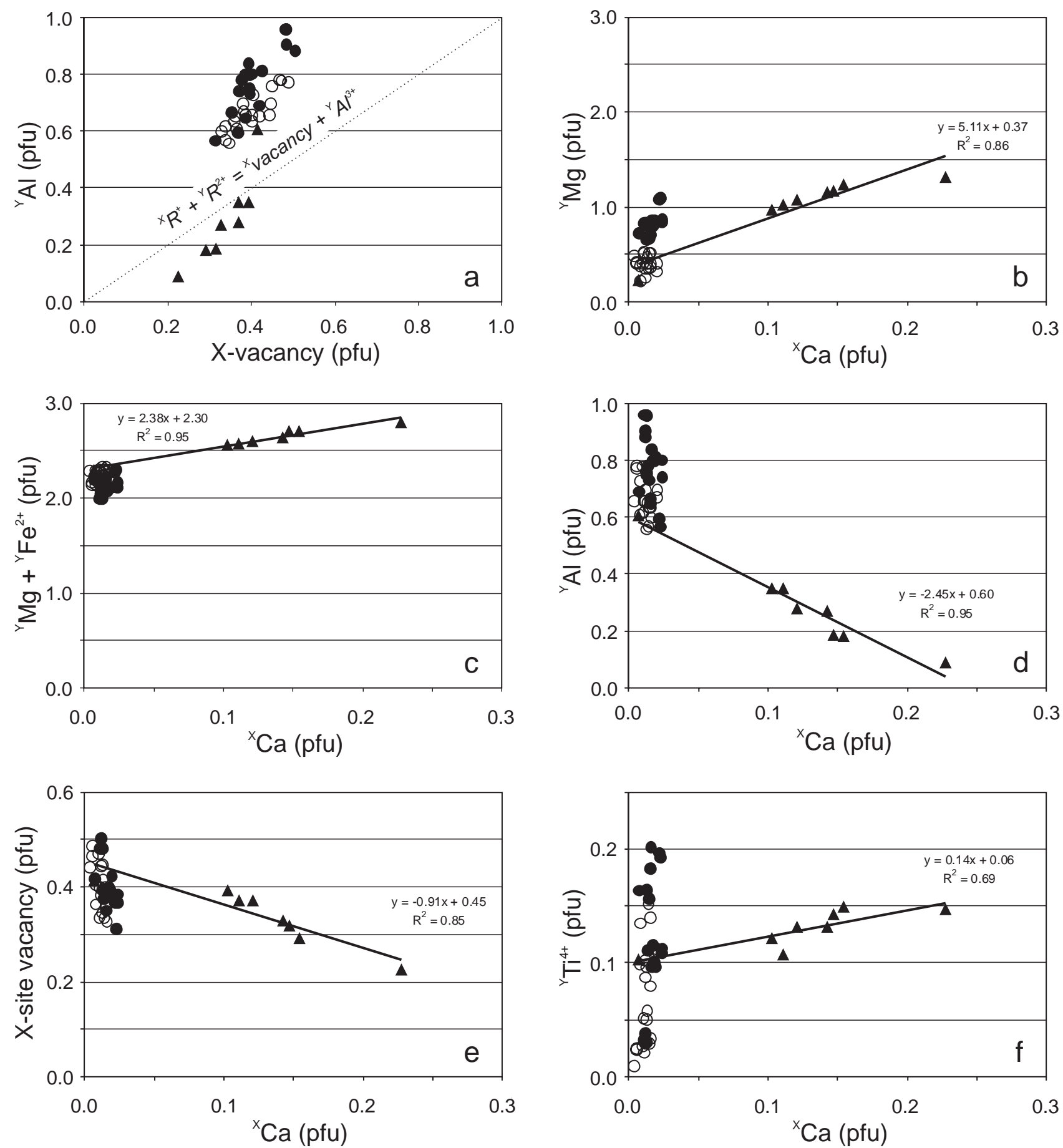

Fig. 11 Compositional relationships in tourmalines from the Julianna-type dykes and veins: $\mathbf{a}-{ }^{\mathrm{Y}} \mathrm{Al}$ vs. $\mathrm{X}$-site vacancy; $\mathbf{b}-{ }^{\mathrm{Y}} \mathrm{Mg}$ vs. ${ }^{\mathrm{x}} \mathrm{Ca}$; $\mathbf{c}-{ }^{\mathrm{Y}}\left(\mathrm{Mg}+\mathrm{Fe}^{2+}\right)$ vs. ${ }^{\mathrm{x}} \mathrm{Ca} ; \mathbf{d}-{ }^{\mathrm{Y}} \mathrm{Al}$ vs. ${ }^{\mathrm{x}} \mathrm{Ca} ; \mathbf{e}-\mathrm{X}$-site vacancy vs. ${ }^{\mathrm{x}} \mathrm{Ca} ; \mathbf{f}-{ }^{\mathrm{Y}} \mathrm{Ti}^{4+}$ vs. ${ }^{\mathrm{x}} \mathrm{Ca}$. Symbols as in Fig. 10.

rounding host rocks (e.g. Galliski et al. 2008; Novák et al. 2012), (2) pre-emplacement contamination of the pegmatite-forming melt, (3) influx of a more primitive pegmatitic melt, (4) competition for the elements among co-crystallizing minerals, and (5) local changes in melt composition.
Contamination of the parental pegmatite-forming melt by host rocks could have easily supplied additional $\mathrm{Fe}, \mathrm{Mg}$, $\mathrm{Ti}, \mathrm{Sn}, \mathrm{Ca}$ and some other elements released by the breakdown of biotite, plagioclase, accessory ilmenite and other oxides present in the surrounding amphibolites. However, real evidence for a significant interaction between the peg- 
Tab. 8 Representative compositions of garnet

\begin{tabular}{|c|c|c|c|c|c|c|}
\hline & P110 & P111 & P113a & P113b & P127a & P127b \\
\hline \multicolumn{7}{|c|}{ wt. \% } \\
\hline $\mathrm{SiO}_{2}$ & 36.33 & 35.83 & 35.89 & 36.83 & 36.15 & 36.59 \\
\hline $\mathrm{TiO}_{2}$ & 0.02 & 0.08 & 0.06 & 0.12 & 0.00 & 0.00 \\
\hline $\mathrm{Al}_{2} \mathrm{O}_{3}$ & 20.94 & 20.57 & 20.44 & 20.90 & 20.83 & 20.76 \\
\hline $\mathrm{Fe}_{2} \mathrm{O}_{3}$ & 0.00 & 0.90 & 0.94 & 0.98 & 0.26 & 1.42 \\
\hline $\mathrm{FeO}$ & 24.53 & 16.86 & 20.89 & 14.66 & 20.75 & 11.26 \\
\hline $\mathrm{MnO}$ & 18.61 & 26.16 & 21.98 & 18.26 & 22.18 & 21.00 \\
\hline $\mathrm{CaO}$ & 0.21 & 0.18 & 0.19 & 8.72 & 0.20 & 9.24 \\
\hline $\mathrm{MgO}$ & 0.06 & 0.03 & 0.10 & 0.20 & 0.11 & 0.11 \\
\hline Total & 100.70 & 100.61 & 100.49 & 100.68 & 100.48 & 100.39 \\
\hline \multicolumn{7}{|c|}{ Content of ions on the basis of $12 \mathrm{O}$ apfu } \\
\hline $\mathrm{Fe}^{2+}$ & 1.683 & 1.161 & 1.441 & 0.986 & 1.427 & 0.760 \\
\hline $\mathrm{Mn}^{2+}$ & 1.293 & 1.825 & 1.536 & 1.243 & 1.545 & 1.435 \\
\hline $\mathrm{Ca}^{2+}$ & 0.018 & 0.016 & 0.017 & 0.751 & 0.018 & 0.798 \\
\hline $\mathrm{Mg}^{2+}$ & 0.008 & 0.004 & 0.012 & 0.024 & 0.014 & 0.014 \\
\hline$\Sigma$ A site & 3.003 & 3.006 & 3.005 & 3.004 & 3.004 & 3.007 \\
\hline $\mathrm{Al}^{3+}$ & 2.001 & 1.944 & 1.941 & 1.937 & 1.987 & 1.919 \\
\hline $\mathrm{Fe}^{3+}$ & 0.000 & 0.056 & 0.058 & 0.060 & 0.016 & 0.086 \\
\hline $\mathrm{Ti}^{4+}$ & 0.001 & 0.005 & 0.004 & 0.007 & 0.000 & 0.000 \\
\hline$\Sigma B$ site & 2.002 & 2.004 & 2.003 & 2.003 & 2.002 & 2.004 \\
\hline $\mathrm{Si}^{4+}$ & 2.980 & 2.952 & 2.960 & 2.961 & 2.972 & 2.952 \\
\hline $\mathrm{Al}^{3+}$ & 0.023 & 0.054 & 0.045 & 0.043 & 0.032 & 0.055 \\
\hline$\Sigma T$ site & 3.003 & 3.006 & 3.005 & 3.004 & 3.004 & 3.007 \\
\hline $\mathrm{O}^{2-}$ & 12 & 12 & 12 & 12 & 12 & 12 \\
\hline$M n /(M n+F e)$ & 0.435 & 0.600 & 0.506 & 0.543 & 0.517 & 0.629 \\
\hline
\end{tabular}

matite and its wall rocks is rather weak. Nevertheless, contamination of the parental pegmatite-forming melt could have taken place in a hypothetical reservoir of the anatectic melt or along the melt's migration path before emplacement. This hypothesis needs further investigation, as no evidence of a late influx of more primitive pegmatitic melt into the Julianna system has been found so far. Readjustment of the compositions of early crystallized biotite and Ca-rich plagioclase (andesine to oligoclase) of the outer pegmatitic zones to the changing physical and chemical conditions of the rapidly cooling melt could supply elements such as $\mathrm{Ca}$ (from plagioclase), $\mathrm{Ti}$ and possibly also $\mathrm{Mg}$ and $\mathrm{Fe}$ (from biotite) to minerals forming in the inner zones of the pegmatites. Such intra-pegmatite element recycling would be more efficient in the largest veins with well-developed textural differentiation and would depend strongly on the lifetime of the pegmatite body. The process was certainly intensified at the hydrothermal stage by alteration, such as the commonly observed chloritization of biotite, albitization and sericitization of plagioclase. Local changes in melt composition had rather second-rank importance, e.g. locally high Ca activity could have induced the crystallization of Ca-rich tourmaline associated with other Ca-rich phases like titanite or epidote-group minerals. A limitation in Ta accessibility seems to have been the main factor in the only incidentally noted progressive $\mathrm{Ta}-\mathrm{Nb}$ fractionation in columbite-(Fe) from the transition

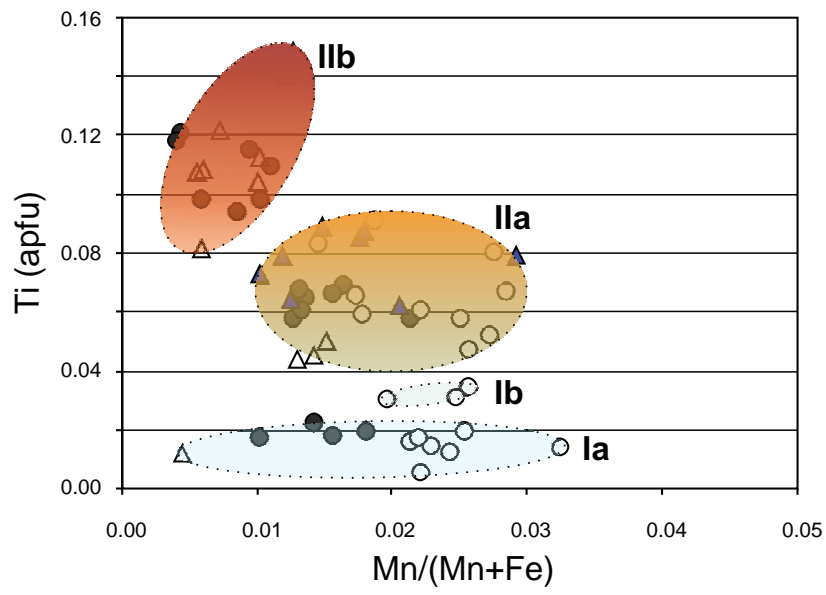

Fig. 12 A correlation between $(\omega)$ pleochroic color of the Juliannatype tourmaline and its composition expressed in binary plot of Ti (in $a p f u)$ vs. $\mathrm{Mn} /(\mathrm{Mn}+\mathrm{Fe})$, the latter expressing the Mn-Fe fractionation. Symbols as in Fig. 10, Ia and $\mathrm{Ib}$ - the crystal core, IIa and IIb - the rim.

between the graphic and massive feldspar intermediate zones. On the other hand, $\mathrm{Nb}-\mathrm{Ta}$ oxides that display the most continuous trend IIb from the progressive through the reversed $\mathrm{Mn}-\mathrm{Fe}$ fractionation (CGM evolving to ixiolite, and ferrowodginite), are those which could evolve in residual melt particularly enriched in volatiles $\left(\mathrm{B}_{2} \mathrm{O}_{3}, \mathrm{H}_{2} \mathrm{O}\right)$. Their occurrence is commonly connected with small nestlike aggregates composed mainly of tourmaline, garnet, abundant muscovite and quartz, where $\mathrm{H}_{2} \mathrm{O}$ activity in the melt was the highest during the pegmatite consolidation and the melt could exist for the longest time.

Acknowledgements. The authors would like to thank reviewers Miguel A. Galliski and Hartmut Beurlen for their helpful discussion on the manuscript. We are par-

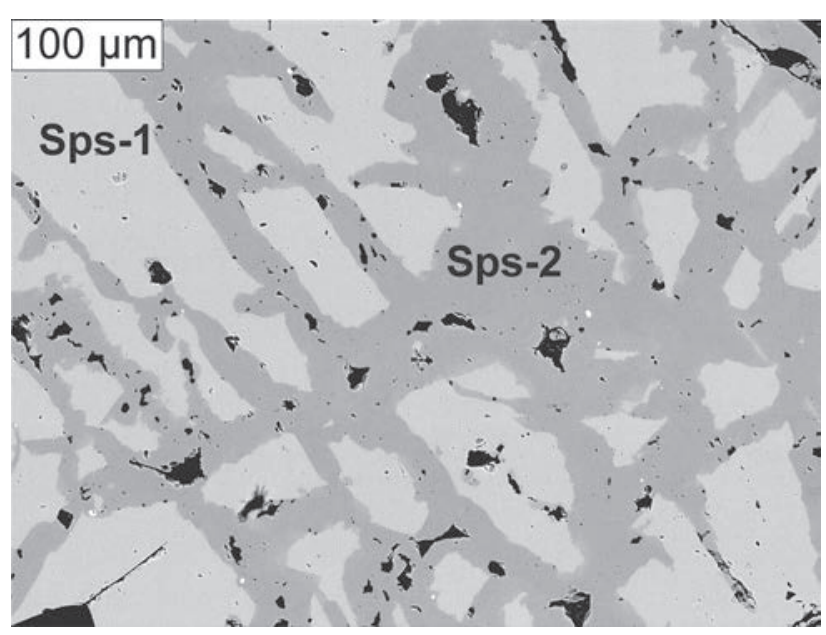

Fig. 13 A back-scattered electron (BSE) image of the 'island' texture in garnet. Abbreviations: Sps-1 - Ca-Mg-poor spessartine, Sps-2 - Carich spessartine. 
ticularly thankful to Jan Łuczak, the first president of the DSS Company, who passed away in 2011, for his great understanding of, and personal involvement and interest in, our research. The work was financially supported by the Ministry of Science and Higher Education and the National Science Centre (NCN) grant N N307 241737 to $\mathrm{AP}$ and the AGH-UST grant 11.11.140.319.

\section{References}

Aftalion M, Bowes DR (2002) U-Pb zircon isotopic evidence for Mid-Devonian migmatite formation in the Góry Sowie domain of the Bohemian Massif, Sudeten Mountains, SW Poland. Neu Jb Mineral, Mh 4: 182-192

BALDWIN JR (1989) Replacement phenomena in tantalum minerals from rare-metal pegmatites in South Africa and Namibia. Mineral Mag 53: 571-581

Beurlen H, Barreto SB, Silva D, Wirth R, Olivier P (2007) Titanian ixiolite-niobian rutile intergrowths from the Borborema Pegmatitic Province, northeastern Brazil. Canad Mineral 45: 1367-1387

Beurlen H, Da Silva MrR, Thomas R, Soares DR, Oliver P (2008) Nb-Ta-(Ti-Sn) oxide mineral chemistry as tracer of rare-element granitic pegmatite fractionation in the Borborema Province, northeastern Brazil. Miner Depos 43: 207-228

BröCKer M, ŻELAźNIEWICZ A, Enders M (1998) Rb-Sr and $\mathrm{U}-\mathrm{Pb}$ geochronology of migmatitic gneisses from the Góry Sowie (West Sudetes, Poland): the importance of MidLate Devonian metamorphism. J Geol 155: 1025-1036

Brueckner HK, Blusztajn J, Bakun-Czubarow N (1996) Trace element and Sm-Nd “age" zoning in garnets from peridotites of the Caledonian and Variscan mountains and tectonic implications. J Metamorph Geol 14: 61-73

ČERNÝ P, ERCIT TS (2005) The classification of granitic pegmatites revisited. Canad Mineral 43: 2005-2026

ČERnÝ P, NovÁK M, Chapman R (1992) Effects of sillimanite-grade metamorphism and shearing on $\mathrm{Nb}-\mathrm{Ta}$ oxide minerals in granitic pegmatites, Maršíkov, northern Moravia, Czechoslovakia. Canad Mineral 30: 699-718

Černý P, Chapman R, Ferreira K, Smeds SA (2004) Geochemistry of oxide minerals of $\mathrm{Nb}, \mathrm{Ta}, \mathrm{Sn}$, and $\mathrm{Sb}$ in the Varuträsk granitic pegmatite, Sweden: the case of "anomalous" columbite-tantalite trend. Amer Miner 89: 505-518

da Fonseca-Zang WA, Zang JW, Hofmeister W (2008) The Ti-influence on the tourmaline colour. J Brazil Chem Soc 19: 1186-1192

DAthe E, Finckh L (1924) Erläuterungen zu Blatt Charlottenbrunn. Geologische Karte von Preußen und benachbarten deutschen Ländern 1:25 000. Lief 254. Preussisches Geologisches Landesamt, Berlin
ERcit TS, Černý P, Hawthorne FC, McGammon CA (1992) The wodginite group. II. Crystal chemistry. Canad Mineral 30: 613-631

FiedLer H (1863) Die Mineralien Schlesiens mit Berücksichtigung der angrenzenden Länder. F. E. C. Leuckart, Breslau, pp 1-100

Galliski MA, Marquez-Zavalía MF, Černý P, Martinez VA, CHAPMAN R (2008) The Ta-Nb-Sn-Ti oxide-mineral paragenesis from LaViquita, a spodumene-bearing rareelement granitic pegmatite, San Luis, Argentina. Canad Mineral 46: 379-393

Gordon SM, Schneider DA, Manecki M, Holm DK (2005) Exhumation and metamorphism of an ultrahigh-grade terrane: geochronometric investigations of the Sudetes Mountains (Bohemia), Poland and Czech Republic. J Geol Soc, London 162: 841-855

Grocholski W (1967) Structure of the Sowie Mts. Geol Sudetica 3: 181-249 (in Polish, English summary)

Gunia T (1985) Geological position of the Sowie Góry Block and its influence on the paleogeography of the Paleozoic of Central Sudetes. Geol Sudetica 20: 83-119 (in Polish, English summary)

Gunia P (1997) Petrology of ultrabasic rocks from the Góry Sowie Block. Prace Geol Miner 65: 1-78 (in Polish, English summary)

Hintze C (1933) Handbuch der Mineralogie, Bd. 1/4, Cruyter and Co., Berlin und Leipzig

Ilnicki S, Nejbert K, Pieczka A, Szelęg E, Turniak K, Szuszkiewicz A, Łodziński M, BANACH M, MichaŁowski P, RÓżNIAK R (2010) Eclogites from the Piława Górna quarry (Dolnośląskie Surowce Skalne S.A.), Góry Sowie Block, SW Poland: a preliminary report. Miner Spec Papers 37: 81

KEPPLER H (1993) Influence of fluorine on the enrichment of high field strength trace elements in granitic rocks. Contrib Mineral Petrol 114: 479-488

Kröner A, Hegner E (1998) Geochemistry, single zircon ages and $\mathrm{Sm}-\mathrm{Nd}$ systematics of granitoid rocks from the Góry Sowie (Owl Mts.), Polish West Sudetes: evidence for early Palaeozoic arc-related plutonism. J Geol Soc, London 155: 711-724

KRYZA R (1981) Migmatization in gneisses of the northern part of the Sowie Góry, Sudetes. Geol Sudetica 16: 7-91 (in Polish, English summary)

Kryza R, FAnNing CM (2007) Devonian deep-crustal metamorphism and exhumation in the Variscan Orogen: evidence from SHRIMP zircon ages from the HT-HP granulites and migmatites of the Góry Sowie (Polish Sudetes). Geodin Acta 20: 159-176

LinNen RL (1998) The solubility of $\mathrm{Nb}-\mathrm{Ta}-\mathrm{Zr}-\mathrm{Hf}-\mathrm{W}$ in granitic melts with $\mathrm{Li}$ and $\mathrm{Li}+\mathrm{F}$ : constraints for mineralization in rare metal granites and pegmatites. Econ Geol 93: 1013-1025

Linnen RL, Keppler H (1997) Columbite solubility in granitic melts: consequences for the enrichment and 
fractionation of $\mathrm{Nb}$ and $\mathrm{Ta}$ in the Earth's crust. Contrib Mineral Petrol 128: 213-227

Łodziński M, PieczKa A (2008) (Nb-Ta)-oxide minerals from pegmatites of the Owiesno-Kietlice area in the Sowie Mts block, Southwestern Poland. Miner Spec Papers 32: 108

Łodziński M, Pieczka A, SzęęG E, Nejbert K, Szuszkiewicz A, Turniak K, Ilnicki S, Banach M, Michalowski P, RóżNıAK R (2010) Beryllium minerals (beryl, phenakite and bavenite) in pegmatites of the DSS mine at Piława Górna, Góry Sowie block, SW Poland. Miner Spec Papers 37: 91-92

MatTson SM, Rossman GR (1987) Identifying characteristics of charge transfer transitions in minerals. Phys Chem Miner 14: 94-99

MoRAwSKi T (1973) The Sowie Góry area and its petrological problems. In: SMULIKowski K (ed) Revue des problèms géologiques des zones profondes de l'écorce terrestre en Basse Silesie. Wydawnictwa Geologiczne, Warszawa, pp 44-58

Nejbert K, Pieczka A, Szelęg E, Ilnicki S, Szuszkiewicz A, Łodziński M, Turniak K, Banach M, Michalowski P, RóżNIAK R (2010) Textural and chemical varieties of garnets in the pegmatites from Piława Górna quarry (Dolnośląskie Surowce Skalne S.A.), Góry Sowie Block, southwestern Poland. Miner Spec Papers 37: 96

NovÁk M (2005) Granitic pegmatites of the Bohemian Massif (Czech Republic); mineralogical, geochemical and regional classification and geological significance Acta Mus Moraviae, Sci Geol 90: 3-75 (in Czech with English summary)

NovÁK M, ČECH F (1995) Scandian columbite and niobian rutile from pegmatites penetrating the Třebíč durbachite massif, western Moravia, Czech Republic. Acta Mus Moraviae, Sci Nat 80: 3-8

NovÁK M, Č́ERNÝ P (2001) Distinctive compositional trends in columbite-tantalite from two segments of the lepidolite pegmatite at Rožná, western Moravia, Czech Republic. J Czech Geol Soc 46: 1-8

NovÁK M, Černý P, Uher P (2003) Extreme variation and apparent reversal of $\mathrm{Nb}-\mathrm{Ta}$ fractionation in columbitegroup minerals from the Scheibengraben beryl-columbite pegmatite, Maršíkov, Czech Republic. Eur J Mineral 15: 565-574

Novák M, ŠKoda R, Gadas P, KRMíček L, ČERnÝ P (2012) Contrasting origin of the mixed (NYF + LCT) signature in granitic pegmatites, with examples from the Moldanubian Zone, Czech Republic. Canad Mineral 50: 1077-1094

O’Brien PJ, Kröner A, Jaeckel P, Hegner E, Żelaźniewicz A, KryzA R (1997) Petrological and isotope studies on Palaeozoic high-pressure granulites. Góry Sowie Mts, Polish Sudetes. J Petrol 38: 433-456

PieczKa A (2010) Primary Nb-Ta minerals in the Szklary pegmatite, Poland: new insights into controls of crystal chemistry and crystallization sequences. Amer Miner 95: 1478-1492

Pieczka A, Gołębiowska B, Skowroński A (2003) Ferrisicklerite and other phosphate minerals from the Lutomia pegmatite (SW Poland, Lower Silesia, Góry Sowie Mts). In: Cемpírek J (ed) International Symposium on Light Elements in Rock-Forming Minerals, Nové Město na Moravě, Czech Republic, June 20 to 25, 2003, Book of Abstracts. Masaryk University \& Moravian Museum, Brno, pp 63-64

Pieczka A, Łobos K, Sachanbiński M (2004) The first occurrence of elbaite in Poland. Miner Pol 35: 3-14

Pieczka A, Szeteg E, Szuszkiewicz A, Łodziński M, Nejbert K, Turniak K, Ilnicki S, Banach M, Michąowski P, RóżNIAK R (2010) Lithium pegmatite from the DSS Piława Górna mine, Góry Sowie Block, southwestern Poland. Mineral Spec Papers 37: 99

Pieczka A, Łodziński M, Szelęg E, Ilnicki S, Nejbert K, Szuszkiewicz A, Turniak K, Banach M, Michalowski P, RóżNIAK R (2012) The Sowie Mts. pegmatites (Lower Silesia, SW Poland): a current knowledge. Acta Mineral Petrograph, Abstract Series 7: 105-106

Polański A. (1955) On the metamorphism of crystalline formations of the Sowie Mts (Middle Sudeten). Arch Mineral 18: 211-284 (in Polish, English summary)

Pouchou IL, Pichoir F (1985) "PAP" $(\phi-\rho-Z))$ procedure for improved quantitative microanalysis. In: ARMSTRONG IT (ed) Microbeam Analysis. San Francisco Press, San Francisco, pp 104-106

RÖMER F (1864) Über die Auffindung des Columbit. Jahresberichte der schlesischen Gesellschaft für vaterländische Cultur 41: 35

Rотн J (1867) Erläuterungen zu der geognostischen Karte von Niederschlesichen Gebirge und den umliegenden Gegenden Berlin, Neumann [8] ss. XX, 396

Szęęg E, Szuszkiewicz A, Pieczka A, Nejbert K, TurNIAK K, LodzińsKi M, ILNicki S (2010) Geology of the Julianna pegmatite vein system from the Piława Górna quarry (Dolnośląskie Surowce Skalne S.A.), Sowie Mountains Block, SW Poland. Mineral Spec Papers 37: 111

Szuszkiewicz A, Szęęg E, Pieczka A, Ilnicki S, Nejbert $\mathrm{K}$, TuRniak K, Banach M, Łodziński M, RóżNiak R, MichaŁOwski P (in print) The Julianna pegmatite vein system at the Piława Górna mine, Góry Sowie Block, SW Poland - preliminary data on geology and descriptive mineralogy. Geol Q 57: doi: 10.7306/gq.1097

Timmermann H, Parrish RR, Noble SR, Kryza R (2000) New U-Pb monazite and zircon data from the Sudetes Mountains in SW Poland; evidence for a single-cycle Variscan Orogeny. J Geol Soc, London 157: 265-268

Tindle AG, Breaks FW (1998) Oxide minerals of the Separation Rapids rare-element granitic pegmatite 
group, northwestern Ontario. Canad Mineral 36: 609-635

Tindle AG, BReaks FW (2000) Columbite-tantalite mineral chemistry from rare-element granitic pegmatites: Separation Lake area, N.W. Ontario, Canada. Mineral Petrol 70: 165-198.

Traube H (1888) Die Minerale Schlesiens. M. Müller, Breslau, pp 1-286

Van Breemen O, Bowes DR, Aftalion M, Żelaźniewicz A (1988) Devonian tectonothermal activity in the Sowie Góry gneissic block, Sudetes, southwestern Poland: evidence from $\mathrm{Rb}-\mathrm{Sr}$ and $\mathrm{U}-\mathrm{Pb}$ isotopic studies. J Pol Geol Soc 58: 3-10

Van Lichtervelde M, Salvi S, Beziat D (2007) Textural features and chemical evolution in tantalum oxides: magmatic versus hydrothermal origin for Ta mineralization in the
Tanco Lower pegmatite, Manitoba, Canada. Econ Geol 102: 257-276

Websky M (1868) Über Sarkopsid und Kochelite, zwei neue Minerale aus Schlesien. Z Dtsch Geol Gesell 20: 245-257

Wise MA, Černý P, FAlster AU (1998) Scandium substitution in columbite-group minerals and ixiolite. Canad Mineral 36: 673-680

ŻELAŹNIEWICZ A (1987) Tectonic and metamorphic evolution of the Góry Sowie, Sudetes Mts, SW Poland. J Pol Geol Soc 57: 203-348

ŻELAŹNIEWICZ A (1990) Deformation and metamorphism in the Góry Sowie gneiss complex, Sudetes, SW Poland. Neu Jb Geol Paläont, Abh 179: 129-157

ŻELAźNIEwicz A (1997) The Sudetes as a Paleozoic orogen in central Europe. Geol Mag 134: 691-702 